\title{
The Tender Years Doctrine: A Defense
}

\author{
Ramsay Laing Klaff $\dagger$
}

All states recognize the welfare or "best interests" of the child as the sole or paramount concern in the resolution of custody disputes between parents following divorce or separation. ${ }^{1}$ The tender years doctrine-under which the mother is the preferred custodian for young children-embodies a presumption that a mother's care is ordinarily in the best interests of a young child. ${ }^{2}$ For more than a century, the doctrine has been the primary determinative factor in the resolution of interparental custody disputes. ${ }^{3}$ In soine states, the tender years doctrine

$\dagger$ B.A. 1977, De Paul University; J.D. 1980, University of Chicago Law School. Currently in private practice in Chicago, Illinois. The author is grateful to Professor Franklin Zimring of the University of Chicago Law School for his guidance and support through earlier drafts of the Article.

1. See Mnookin, Child-Custody Adjudication: Judicial Functions in the Face of Indeterminacy, 39 LAw \& CONTEMP. PROBS. 226, 236-37 (1975). The origims of the best interests principle are discussed infra in Part 1.

2. Sce, e.g., Claffey v. Claffey, 135 Conn. $374,377,64$ A.2d 540, 542 (1949) ("that under normal circumstances, the interests of a young child . . . will be best served by growing up in the care of [its] mother does not admit of question"); UNIFORM MARRIAGE AND DIVORCE ACT \& 402, Commissioner's Note (1973) ("The preference for the mother . . . is simply a shorthand method of expressing the best interest of children - and this section enjoins judges to decide custody cases according to that general standard"). The tender years presumption should not be confused with the very different rule used in disputes between a natural mother and third parties, under which the mother is entitled to custody absent a showing of her unfitness. The tender years doctrine as applied to divorce custody law is not now, and never has been, a doctrine of preferential entitlement. Rather, fathers in all American jurisdictions always have had an equal or paramount legal right to the custody of their legitimate children. See infra Part I.

3. It has been estimated that mothers retain custody after divorce more than $90 \%$ of the time. See, e.g., W. Goode, Women IN Divorce 311 (1965) (94.8\%); Drinan, The Rights of Children in Modern American Family Law, 2 J. FAM. L. 101, 102 (1962). Disagreements over some aspect of custodial arrangements appear to arise, however, in only $10 \%$ of divorces involving children. Sce W. GooDE, supra, at 313; Weitzman \& Dixon, Child Custody Awards: Legal Standards and Empirical Patterns for Child Custody, Support and Visitation After Divorce, 12 U.C.D. L. REv. 473,521 (1979). Most custodial arrangements are the result of private agreements between the parents. Some jurisdictions may require judicial confirmation of the parents' agreement. See, e.g., Conn. Gen. Stat. ANN. $\$ \S 46 \mathrm{~b}-66$ (West Supp. 1981). Although courts are not bound to accept such consensual arrangements, see, e.g., Koslowsky v. Koslowsky, 41 Wis. 2d 275, 283, 163 N.W.2d 632, 636 (1969), they generally do. See W. GOODE, supra at 163. The rubberstamping of consensual agreements is strongly endorsed by most commentators. See, e.g., J. GoldstEIN, A. FREUd \& A. SOLNIT, Before tHE BEST INTERESTS OF THE ChILd 33, 193 (1979); Mnookin, supra note 1, at 288 \& n.248. But see Leavall, Custody Disputes and the Proposed Model Act, 2 GA. L. REv. 162, 190-91 (1968). 
has taken the form of a legal presumption; ${ }^{4}$ in most, it has been expressed as a "rule of thumb" or "natural presumption."5 Both forms traditionally have dictated inaternal custody unless the father could prove the mother an "unfit" custodian. ${ }^{6}$

In the wake of contemporary concern about gender-specific classifications, however, the doctrme has become the focus of adverse commentary, ${ }^{7}$ legislation, ${ }^{8}$ and judicial decisions. The high-water mark of this trend was reached in 1973 when Judge Sybil Hart Kooper of the Family Court of New York held in Watts $v$. Watts ${ }^{9}$ that any presumptive preference in favor of maternal custody violated the father's right to equal protection under the fourteenth amendment. ${ }^{10}$ More generally, critics contend that the doctrime is outdated. They typically advocate an alternative approach in which the trial court makes ad hoc determinations of what is "best" for a given child."

This Article will argue that the present call to abandon the tender years doctrine in the name of legal equality between the sexes is mis-

4. See, e.g., OKLa. Stat. AnN. tit. 30, § 11 (West 1976).

5. See, e.g., Esposito v. Esposito, 41 N.J. 143, 145, 195 A.2d 295, 296 (1963).

6. See, e.g., Stafford v. Stafford, 287 Ky. 804, 155 S.W.2d 220 (1941).

7. See, e.g., Roth, The Tender Years Presumption in Child Custody Disputes, 15 J. FAM. L. 423 (1976).

8. See, e.g., CAL. CIv. CODE $\S 4600$ (West Supp. 1981) (repealing statutory preference for maternal custody of young children). According to one commentary, as of 1978 seven states had passed "deseximg" statutes, prohibiting custody decisions based solely on gender. See Foster \& Freed, Life with Father: 1978, 11 FAM. L.Q. 321, 343-63 (1978). The Wisconsin statute, for example, provides that the court "shall not prefer one potential custodian over the other on the basis of the sex of the custodian." WIS. FAM. Code $\$ 767.24$ (d)(2) (West Supp. 1981). However, courts have split on the question of whether such desexing statutes are inconsistent with a presumption in favor of inaternal custody. Compare Scolman v. Scolman, 66 Wis. 2d 761, 226 N.E.2d 388 (1975) (maternal preference not elimmated) with Erwin v. Erwin, 505 S.W.2d 370, 372 n.1 (Tex. Civ. App. 1974) (Inaternal preference abohished).

One court has resolved the apparent conflict between a desexing statute and the traditional presumption in favor of naternal custody by replacing the traditional presumption with a genderneutral preference for the primary caregiving parent. See Garska v. McCoy, 278 S.E.2d 357 (W. Va. 1981). A primary caregiver preference also appears to operate sub silentio in California where the vast inajority of cases result in inaternal custody despite the 1973 abolition of a statutory maternal preference presumption. See Weitzman \& Dixon, supra note 3, at 521.

9. 77 Misc. 2d 178, 350 N.Y.S.2d 285 (Fam. Ct. 1973).

10. The Alabama Supreme Court has held more narrowly that a rule dictating maternal custody absent a slowing of the mother's unfitness violates the 14th amendment. Devine v. Devine, 398 So. $2 \mathrm{~d} 686$ (Ala. 1981). Cf., e.g., King v. Vancil, 34 Ill. App. 3d 831, 836, 341 N.E.2d 65, 69 (1975) (preference for mother absent showing of unfitness violates state equal rights amendment).

A result contrary to Watts was reached by the Oklahoma Supreme Court, which upheld that state's statutory preference for maternal custody "other things being equal." Gordon v. Gordon, 577 P.2d 1271 (Okla.), cert. denied, 439 U.S. 863 (1978). Cf. Kirstukas v. Kirstukas, 14 Md. App. 190, 286 A.2d 535 (1975) (maternal preference upheld despite state equal rights amendinent); Cox v. Cox, 532 P.2d 994 (Utah 1975) (maternal preference does not violate state equal rights amendment).

11. See, e.g., Foster \& Freed, supra note 8; Roth, supra note 7, at 457-59. 
conceived and retrograde, however fashionable. The doctrine originated in the nineteenth century as a child-protective reform intended to elevate the interests of children above fathers' common law proprietary rights in children. Enlightened application of the doctrine is consonant with the best existing knowledge of child development and inore child-protective than alternative approaches advocated by critics of the doctrine. Abandonment of the doctrine therefore would serve only to resubordinate child welfare to protection of proprietary parental interests in children. The fourteenth annendment does not compel this result.

Part I of this Article reviews the development of the tender years doctrine as a reform of the common law of domestic relations. Part II defends a rebuttable tender years presumption as sound child welfare policy. Part III addresses the constitutional issues raised by the Watts decision.

I

HISTORICAL BACKGROUND

Under the common law, a father had an absolute right to the control and custody of his legitimate ${ }^{12}$ minor children. Parental rights were property rights ${ }^{13}$ and, like other property rights acquired during marriage, they vested exclusively in the husband. Mothers were, as Blackstone put it, entitled "only to reverence and respect," 14 while children had no enforceable rights against their parents. Thus when parents separated ${ }^{15}$ and disagreed about living arrangenents for their children, the father's interest alone was entitled to legal protection.

Before 1763, the father's right to custody apparently had no limitation. That year, however, in Rex v. Delaval, ${ }^{16}$ Lord Mansfield cast doubt on the inviolability of paternal rights for the first time when he demied a father's writ of habeas corpus ${ }^{17}$ for the return of an eighteen-

12. Putative fathers were not entitled under the common law to custody of their illegitimate children as against the mother. See Rex v. Soper, 101 Eng. Rep. 156 (K.B. 1793).

13. 1 W. BlaCKSTONE, COMMENTARIES 452-53. Among other thimgs, a father could assign his parental rights, without the mother's consent, to a third party both during the father's hife and by will. Id. at 453 .

14. Id. See, e.g., Gates v. Renfroe, 7 La. Ann. 569 (1852) (under both the civil and common law, mimors subjected exclusively to the authority of the father); Pame v. Paine, 23 Tenn. (4 Hum.) 523 (1843) (wife has no common law right to custody of the children as against the husband).

15. Total divorce was not obtamable in England and most American states until the mid19 th century, but neither legal nor inforinal separations were uncommon in the preceding century. See generally Mueller, Inquiry into the State of a Divorceless Society, Domestic Relation Law and Morals in England from 1660 to 1857, 18 U. P1Tr. L. REv. 545 (1957).

16. 97 Eng. Rep. 913 (K.B. 1763) (Mansfield, C.J.).

17. Because the father was by right entitled to custody, the common law had no special procedure to adjudicate placement decisions. Any custody other than that of the father was illegal, and the proper writ therefore was habeas corpus. 
year-old daughter. The young woman had been apprenticed to a musician who had subsequently delivered her to Lord Delaval for prostitution. Instead of restoring the girl to her father and mother, Lord Mansfield emancipated her. Since there was no precedent for refusing paternal custody of a minor, Lord Mansfield undertook to "clarify" the governing rule. Previous cases honoring paternal rights had been correct in result, he stated, but not in reasoning. Minors had been restored to their fathers (or legal guardians), not because the courts were bound to so dehiver them, but because such a result had been appropriate on the facts of each case. The "true rule," therefore, was that "the Court are [sic] to judge upon the circumstances of the particular case, and to give their directions accordingly." 18

Two years later in Blissets Case, ${ }^{19}$ Lord Mansfield followed his clarified rule and allowed a six-year-old child to remain with her mother where the father earher had abandoned the family. Two rationales were advanced to support the holding. The broader rationale was that "if the parties are disagreed, the court will do what shall appear best for the child." 20 This rule is nothing less than the modern "best interests of the child" principle. The narrower rationale was that a father who abandoned his parental duties forfeited his parental rights. ${ }^{21}$ This rationale has its modern counterpart in the "unfitness" doctrine under which a parent may be deprived of custody because of objectionable social conduct, often without regard to the child's welfare.

Lord Mansfield's attempted reform of domestic relations law was soinewhat premature. Subsequent Enghish cases ignored the best interests principle altogether and confined the ruling in Blissets Case to its facts. In Rex v. DeManneville, ${ }^{22}$ for example, a father succeeded in retaining custody of his eight-month-old daughter, although the mother was breastfeeding the infant and had left the father because of his cruelty. Lord Ellenborough doubted the authority of Lord Mansfield's earlier opinions and stated that in any event a father could not be deprived of a child "fairly" in his custody-that is, a child he had not financially abandoned. In Ex parte Skinner, ${ }^{23}$ the mother was refused custody of a six-year-old child whom the father had placed with his inistress while he was in debtor's prison.

On two occasions Chancery did deny paternal rights for what was

18. 97 Eng. Rep. at 914.

19. 98 Eng. Rep. 899 (K.B. 1774) (Mansfield, C.J.).

20. Id. at 899 .

21. Id.

22. 102 Eng. Rep. 1054 (K.B. 1804) (Ellenborough, C.J.). Chancery did, however, later intervene to order the father not to remove the child from England. DeManneville v. DeManneville, 32 Eng. Rep. 762 (Ch. 1804).

23. 27 Rev. Rep. 710 (C.P. 1824). 
later termed "gross profligacy." 24 In 1817, the poet Percy Bysshe Shelley's parental rights were terminated because of his publicly avowed atheism when he sought to obtam his children from the maternal grandparents following his wife's death. ${ }^{25}$ In 1827, in Wellesley v. Duke of Beaufort, ${ }^{26}$ a father agam lost custody to maternal relatives after the mother's death. The husband had had a longstanding liaison with another woman, whom he had at one point kept under the same roof with his wife and children. Moreover, the wife, prior to her death, had tried to secure a divorce and have the children declared wards of the king. The Lord Chancellor wrote, "I say that, if the House of Lords think [it] proper to restore these children to [their father], let thein do so; it shall not be done by my act."27

In the same year, however, the Vice Chancellor, Sir Anthony Hart, thought himself powerless to grant a mother's petition to retam physical custody of, or be guaranteed access to, her fourteen-year-old daughter despite the father's alleged brutahty and misconduct:

I do not know of any one Case similar to this, which would authorise my making the Order sought, in either alternative. If any could be found, I would most gladly adopt it; for, in a moral point of view, I know of no act more harsh or cruel, than depriving the mother of proper intercourse with her Child. ${ }^{28}$

Thus three decades into the nineteenth century, all that was left of Lord Mansfield's early attempt to modify proprietary paternal rights was the somewhat uncertain authority of Chancery to intervene in extraordinary cases of scandalous immorality. ${ }^{29}$

The case that precipitated reform in England was Rex v. Greenhill. ${ }^{30}$ The father had left his family to set up housekeeping with his

24. Rex. v. Greenhill, 111 Eng. Rep. 922, 928 (K.B. 1836) (Denman, C.J.).

25. Shelley v. Westbrooke, 37 Eng. Rep. 850 (Ch. 1817).

26. 38 Eng. Rep. 236 (Ch. 1827).

27. Id. at 251 .

28. Ball v. Ball, 57 Eng. Rep. 703, 704 (V.C. 1827).

29. Apparently, courts rarely were called upon to enforce a father's right. There are no reported interspousal cases before 1773 and only a handful of English cases reported between then and 1839 when the law was changed. There were surely unreported cases and instances in which children were simply removed from the mother by the father withont recourse by either party to legal proceedings. The paucity of cases nevertheless suggests that then, as now, hiving and support arrangements after parental separation typically were agreed upon privately by the parents. Since it is not likely that nothers routinely gave up their children voluntarily, the pancity of cases also suggests that fathers then, as now, typically allowed young children to remain with their mothers. It also seems likely that the harshness of the paterual custody rule was principally felt, as one reformer observed, in its "silent operation" as a tool of doinestic tyranny. 39 PARL. DEB. (3d ser.) 1082-91 (1837) (speech of Serjeant Talfourd). For most women, the loss of access to a young child likely was, except im extreine circunstances, too high a price to pay for disobedience or the limited frecdoin of a partial divorce. Consequently, a husband had only to threaten removal of the children in order to make his wife's conduct conform to his demands or to prevent a separation.

30. 111 Eng. Rep. 922 (K.B. 1836). 
mistress. The mother then had moved to her parents' home with the children, three daughters under the age of six. In an attempt to force a reconciliation with his wife, the father brought a writ of habeas corpus for the children. The mother refused to return to the marital home and sought to retaim the children in her care. After thoroughly reviewing the law on the subject, the court concluded that it was without authority to deny the father custody. The mother, in desperation, took the children and expatriated to the Continent, while the counsel for the father, Serjeant Talfourd, began a campaign in Parliament to change the law. In an impassioned speech in the House of Commons, Talfourd recited a litany of domestic lorror stories and pleaded for recognition of "natural justice." ${ }^{31}$ Lord Denman, who had presided in the case, stated that all judges were ashamed of the law on the subject. ${ }^{32}$ The resulting reform statute gave Chancery discretionary power to order maternal custody for children under seven and maternal visitation rights for children of any age provided the mother had not been found guilty of adultery. ${ }^{33}$ In 1873 , maternal custody was authorized for children up to sixteen. ${ }^{34}$ These statutes are the source of the tender years doctrime in England. Thereafter young children were customarily placed in the custody of their mothers.

In this country, the tender years doctrine was introduced, along with the best imterest principle, in an 1813 Pennsylvania case, Commonwealth $v$. Addicks. ${ }^{35}$ The father, Lee, sought custody of two daughters, aged ten and seven, who were living with their mother and her second husband, Addicks. The mother had had a child by Addicks and had lived with him while still married to Lee, for which cause Lee was granted a divorce. Moreover, the second marriage was void because of a statute prohibiting the wife from marrying her paramour during her liusband's lifetime. The father, on the other hand, had abandoned the mother and daughters four years earlier.

The court, paraphrasing and citing Lord Mansfield's opinion in Rex $v$. Delaval, ${ }^{36}$ held that the court was not bound to restore the children to their father and would do so only "if we think that, under the circumstances of the case, it ought to be done." ${ }^{.37}$ The court then ordered maternal custody:

We cannot avoid expressing our disapprobation of the mother's conduct, although so far as regards her treatment of the children, she is $\mathrm{m}$

\footnotetext{
31. Parl. Deb. (3d ser.) 1087 (1837) (speech of Serjeant Talfourd).

32. Id. (speech of Lord Denman).

33. Act to Ameud the Law Relating to Custody of Infants, 2 \& 3 Vict., ch. 54 (1839).

34. Act to Amend the Law Relating to Custody of Infants, 36 \& 37 Vict., ch. 12 (1873).

35. 5 Binn. 520 ( $\mathrm{Pa} .1813)$.

36. 97 Eng. Rep. 913 (K.B. 1763) (Mansfield, C.J.).

37. 5 Binn. at 521 .
} 
no fault. . . . It is to them, that our anxiety is principally directed; and it appears to us that considering their tender age, they stand in need of that kind of assistance, which can be afforded by none so well as a mother. It is on their account, therefore, that exercising the discretion with which the law has invested us, we think it best, at present, not to take them from her. ${ }^{38}$

The principle that courts are empowered to subordinate proprietary parental imterests in a child to a paramount concern for the interests of the child was rapidly adopted by other jurisdictions ${ }^{39}$ and is today, as noted at the outset of this Article, the governing principle of custody law. ${ }^{40}$ Similarly, the presumption that maternal custody is ordimarily best for young children had been adopted in virtually all jurisdictions by the end of the nineteenth century either by case law under the best imterests principle ${ }^{41}$ or, particularly in the frontier states, directly by statute. ${ }^{42}$

In the context of interparental custody disputes, the best interests of the child principle permits a state, in exercise of its parens patriae power, to place a child with either parent wholly on the basis of the child's welfare and without regard to the respective legal entitlements of the parents. In other contexts, the best imterests principle permits a state to resolve custody disputes between natural parents and third parties in favor of third parties, to remove a child from the custody of its parents, to subrogate or terminate parental rights; and, in the case of adoption, to create parental rights.

The preference for maternal custody for young children-the tender years doctrine - is not a legal principle, but an evidentiary presumption employed under the best interests principle. Thus, the tender years doctrine did not alter the legal rights of mothers. Indeed, in England and in most American jurisdictions equal parental rights were not extended to women until this century. ${ }^{43}$

38. Id. at 521-22.

39. See, e.g., United States v. Green, 26 F. Cas. 30 (C.C.R.I. 1824) (No. 15,256); In re Waldron, 13 Johns. 418 (N.Y. 1816).

40. See Mnookin, supra note 1.

41. See, e.g., Helms v. Franciscus, 2 Bl. Ch. 544 (Md. 1830); People ex rel. Barry v. Mercein, 8 Paige Ch. 46 (N.Y. 1839); McKinı v. McKim, 12 R.I. 462 (1879).

42. See, e.g., CAL. Civ. Code $§ 138$ (1872); 1879 Mich. Pub. Acts 163; 1860 N.J. Laws, ch. 167; OKLA. STAT. ch. 63 \& 11 (1890).

43. Kansas, in 1859 , was the first state to recognize equal parental rights for women. KAN. CoNsT. art. $15, \S 6$. By 1900 , only 30 more states had followed suit. Nime states still had not recognized equal parental rights for women by 1930 . In England, nothers were given equal parental rights in 1925. G. ABbott, The Child AND the StATE 8 (1938); 1 Report of the Presi-

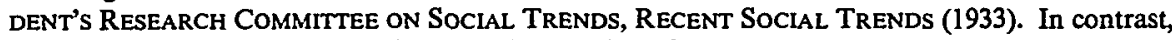
by 1900 all nuarried wonen in the United States had the right to own separate property and to make wills except in a few southeast and westcrn states where the civil law systein of community property affecting husband and wife alike was adopted. 
Unlike the parental custody rule based on the father's legal right to custody, the maternal preference presumption was limited from the outset to mothers innocent of marital fault. ${ }^{44}$ The two daughters in the Addicks case, for example, were subsequently restored to their father's custody because of the mother's adultery. ${ }^{45}$ More broadly, the doctrine operated only where the mother was a fit and proper custodian. By the time mothers were placed on an equal legal footing with fathers, the preference for maternal custody was so firmly entrenched that it could be defeated only if the mother was shown to be unfit. ${ }^{46}$

II

\section{The Best Interests of THE ChILD}

Under the tender years doctrine, every custody dispute between parents begins with the presumption that maternal custody is best for the child. The father then has the burden of disproving the presumption by meetimg the prevailing standard of rebuttal. If he fails, which typically happens, ${ }^{47}$ the mother is awarded custody. If he succeeds, he is awarded custody. Traditionally, fathers have been required to prove the mother "unfit" for custodianship in order to rebut the presumption. For reasons discussed later in this section, ${ }^{48}$ the "unfitness" standard is insufficiently child protective and therefore indefensible under the best interests principle. Most modern courts applying the doctrine require instead a showing that maternal custody is not in the child's best interests. ${ }^{49}$ This analysis calls the refined doctrine a "rebuttable tender

44. See, e.g., Commonwealth v. Briggs, 32 Mass. (16 Pick.) 203, 204 (1834) ("the Court ought not to sanction the unauthorized separation of husband and wife, by ordering the child into the custody of the mother, thus separated and out of the custody of the father"); People ex rel. Olmstead v. Olmstead, 27 Barb. 9, 3I (N.Y. 1857) ("It has never been dreamed that, when the mother has been at fault in the occurrences preceding the separation, she should be rewarded for her faults by the interposition of the courts.").

45. Commonwealth v. Addicks \& Lee, 2 Serg. \& Rawle 174 (Pa. 1815). Chief Justice Tilgh. unan, who had written the opinion in the first Addicks case, concluded that "when [the children] inquire, why it was that they were separated from their mother, they will be taught, as far as our opinions can teach them, that in good fortune or in bad, in sickness or in health, in happiness or in misery, the marriage contract, unless dissolved by the law of the country is sacred and inviolable." Id. at 177. He recommended, however, that the father not "be abrupt in their removal, but to conduct the matter so as to avoid a violent shock either to thein or their mother." Id.

46. See, e.g., Stafford v. Stafford, 287 Ky. 804, 155 S.W.2d 220 (1941); Whatley v. Whatley, 312 So. $2 d 149$ (La. Ct. App. 1975).

47. See supra note 3.

48. See infra notes 73-87 and accompanying text.

49. See, e.g., Garrett v. Garrett, 464 S.W.2d 740 (Mo. Ct. App. 1971); Gordon v. Gordon, 577 P.2d 1271, 1277 (Okla.), cert. dented, 439 U.S. 863 (1978); Masek v. Masek, 89 S.D. 62, 66, 228 N.W.2d 334, 336 (1975); Scolman v. Scolman, 66 Wis. 2d 761, 766-67, 226 N.W.2d 388, 391 (1975). Some courts emphasize that the maternal preference operates only where "other things are equal." See, e.g., Gordon v. Gordon, 577 P.2d 1271, 1277 (Okla.), cert. denied, 439 U.S. 863 (1978). Because "other things" typically must pertain directly to the parent-child relationships and because most "other things" are indeterminate with respect to what is "best" for a particular child, see 
years presumption" and defines the standard of rebuttal more explicitly as a positive showing by a preponderance of the evidence that paternal custody will better serve the child's immediate developmental needs than will maternal custody. With one caveat, application of the rebuttable tender years presumption is more child protective than alternative approaches advocated by critics. The caveat is that the presumption should not be used to award custody to one parent where joint custody is both feasible and desirable for the child. It is, however, appropriate to use the presumption in joint custody cases to designate the parent with whom the child will have its primary residence where, as is often the case, an equal division of time between parents having joint custody would be too disruptive for the child.

\section{A. The Rebuttable Tender Years Presumption}

\section{Underlying Assumptions}

The presumption that it is ordinarily in a young child's best interests to be in its mother's care rests on two assumptions. The first, an assumption about children, is that a child's primary need is for the care and love of its mother. ${ }^{50}$ The second assuinption is about parents and holds that the mother is likely to be better able than the father to provide the care and attention that a young child needs. ${ }^{51}$ The first assumption has been criticized as "wool-sack socio-psychology" on the grounds that what a child needs is not its mother, but "mothering," a function that can be performed by someone other than the biological mother. ${ }^{52}$ The second assumption has been criticized as outdated sexual stereotyping. Men, it is argued, are just as capable as women of performing childrearing functions. ${ }^{53}$

Even acceptimg for the moment that mothering may be a genderneutral function, this line of argument against the tender years doctrine is flawed. It assumes that the maternal preference is based solely on

infra notes 75-84 and accompanying text, "other things being equal" in actuality means "other things being indetermmate." Therefore, a tie-breaker preference for the nother-"other things being equal" - is functionally equivalent to the rebuttable tender years presumption described in the text; inaternal custody is presuined best for the child absent a positive showing that it is not.

50. The traditional expression is that "there is no substitute for a inother's love." See, e.g., Waslıburn v. Wasliburn, 49 Cal. App. 2d 581, 584, 122 P.2d 96, 100 (2d Dist. 1942). See also Kirstukas v. Kirstukas, 14 Md. App. 190, 286 A.2d 535, 538 (1972) (preference for the mother "is simply a recognition by the law, as well as by the commonality of inan, of the universal verity that the maternal tie is so primordial that it slould not lightly be severed or attenuated").

51. See, eg., Sheelian v. Sheehan, 51 N.J. Super. 276, 290-91, 143 A.2d 874, 882 (1958) (the mother is preferred "upon the theory that [she] will take better and nore expert care of [the] child than the father"). See generally Hammett v. Hammett, 46 Ala. App. 206, 239 So. 2d 778, 780 (Civ. App. 1970).

52. Roth, supra note 7 , at $436-37 \&$ n.51.

53. Watts v. Watts, 77 Misc. 2d 178, 181, 350 N.Y.S.2d 285, 289 (Fam. Ct. 1973). 
gender and/or biological notherhood, while in actuality the preference is based principally on the fact that the mother has performed the mothering function - that is, that she has been the primary caregiving parent. $^{\text {s4 }}$ In short, the presumption in favor of maternal custody encompasses both a policy presumption agamst separating a child from his primary caregiving parent (that is, the parent who has unothered him) and a factual presuunption that the primary caregiving parent is the mother.

Whether it is constitutionally permissible to use gender as a proxy for "primary caregiving parent" is discussed in Part III. ${ }^{55}$ Here, I ain concerned only witl showing that a rebuttable presumption im favor of maternal custody is sound child-welfare pohcy. Thus, for the present it is sufficient to note that the mother typically is the primary caregiving parent and that where she is not, the presunption can be rebutted. ${ }^{56}$

Returning then to the validity of the underlying assumptions, the notion that a child's primary need is for the care and love of its mother, where sle has been its primary caregiving parent, is supported by a vast body of psychological literature. Empirical studies show that mother-

54. See, e.g., Garrett v. Garrett, 464 S.W.2d 740, 742 (Mo. Cl. App. 1971) (maternal preference is "predicated upon the acts of motherhood-not the fact of motherhood").

55. Also discussed in Part III is the extent to which gender or biological mothcrhood is relevant to placement decisious under the best interests principle.

56. Most married mothers still do not work outside the home while their children are very young. See infra note 133. The tern "primary caregiving parent" docs not distinguish, however, between mothers who are also wage earners and inothers who are not. Solne commentators appear to Inaintain that a wolnan who works outside the hoine is only biologically a mother. One student commentator has suggested, for exaunple, that mothers who worked before the divorce or who will have to work after the divorce should be treated in effect as "fathers." Note, Measuring the Child's Best Interests-A Study of Incomplete Considerations, 44 DEN. L.J. 132, 138-42 (1967). See also Podell, Peck \& First, Custody-To Which Parent?, 56 Marq. L. Rev. 51, 53 (1972) (quoting and endorsing the student commentary above). Some courts have had similar difficulty in adjusting to the fact that unany mothers are also wage earners. In Masck v. Masek, 89 S.D. 62,228 N.W.2d 334 (1975), for example, the trial judge concluded that the inother's "primary interest lay outside her hoine and family." The supporting evidence meluded these findings: that the inother worked part-time as a inusic instructor; the father (who worked full-time) did the family marketing; the mother did not prepare breakfast for the father and slept in on Saturday inornings until 9 a.m.; and finally that after the separation the father had noticed an einpty jelly jar and no replacement on one visit to the mother's hoine and on another occasion found "a lack of Ho-Ho's, a pastry which the children enjoy." Id. at 68-69, 228 N.W.2d at 338 (Wallman, J., dissenting). See infra note 87 for a discussion of the nother's alleged drinking problein.

While soine women inay choose occupatious that make mothering and wage earning incompatible, the notion that a woinan cannot be both a caregiver and a wage earner or have other interests in addition to inothering and hoinemaking has been soundly refuted. In determining whether a mother is the primary caregiving parent-an issue of fact-the qucstion to ask is whether she has had the primary responsibility, as between the two parents, for meeting the child's day-to-day needs. What she does im addition to meeting that responsibility nay be relevant to the child's welfare, but it is not relevant to the question of whether she is the primary caregiving parent. 
infant "bonding" begins at the child's birth ${ }^{57}$ and that infants as young as two inonths old frequently show signs of distress when the mother is replaced by a substitute caregiver. ${ }^{58}$ An infant typically responds preferentially to the sound of its mother's voice by four weeks, ${ }^{59}$ actively demands her presence and protests her absence by eight inonths, ${ }^{60}$ and within the first year has formed a profound and enduring attachinent to her. ${ }^{61}$ Psychological theory hypothesizes that the mother is the center of an infant's small world, his psychological homebase, and that she "inust continue to be so for some years to coine."62 Developmental psychologists beheve that the quahity and strength of this original bond largely determines the child's later capacity to fulfill his individual potential and to form attachinents to other individuals and to the human community. ${ }^{63}$

A child deprived im infancy of the opportumity to form such a relationship with its nother or a permanent mother-substitute ${ }^{64}$ will be retarded in its physical, imtellectual, and social developinent and runs a high risk of being permanently aftlicted with a nonattachınent person-

57. See generally M. KLaus \& J. Kennell, Maternal Infant Bonding (1976).

58. Nagera, Children's Reactions to the Death of Important Objects, 25 PsYchoANalytic STUDY OF THE CHILD 360, 369 (1970).

59. Wolff, Observations on the Early Development of Smiling, in 2 DETERMINANTS OF INFANT BEHAVIOR 113, 123 (B. Foss ed. 1963).

60. See S. Fraiberg, Every Child's Birthright: In Defense of Mothering 59 (1977):

[A]t about eight months of age the baby demonstrates through his smile a clear discrimination of the mother's face from the faces of other familiar persons or the face of a stranger. . . . [A]nd the baby shows his need for her and his attachment to her by distress when she leaves him and by grief reactions when abseuce is prolonged beyond his tolerance.

See generally R. SiIt, The First Year of Life 150-66 (1965).

61. See S. Fraiberg, supra note 60 , at 30 :

[A]Iready at the end of the first year, the baby has gone through a sequence of phases in his human attachmeuts: from simple recognition of the mother, to recognition of her as a special person, to the discovery that she is the source of joy, the satisfier of body hungers, the comforter, the protector, the indispensable person of his world. In short, he has learned to love.

See generally R. SpITz, supra note 60 , at 122-95. Spitz uses the term "dyad" to describe the mother-child relationship: "It is a relationship that in a certain measure is insulated from the surround, and held together by extraordinary affective bonds. If love could be called 'an egoisin of two' by a French philosopher, that applies a hundredfold to the mother-child relation. Id. at 127.

62. S. FralBERG, supra note 60 , at 31 . The scope of the tender years doctrine is discussed infra notes $90-94$ and accompanying text.

63. See, e.g., M. Klaus \& J. KenNell, supra note 57, quoted in M. WALkeR, B. Yoffe \& P. GRAY, THE COMPLETE BOOK OF BiRTH 23 (1979):

This original mother-infant bond is the wellspring for all the infant's subsequent attachments and is the formative relationship in the course of which the child develops a sense of himself. Throughout his lifetime the strength and character of this attachment will influence the quality of all future bonds to other individuals.

See generally S. FraIBERG, supra note 60, at 45-62.

64. A foster or adoptive mother, for example, not a babysitter or day-care attendant. 
ahty disorder. ${ }^{65}$ Disruption of an ongoing inother-child relationship carries with it similar risks of dainage to the child's immediate wellbeing and future development. ${ }^{66}$ Disruption of the bonding process at any point after birth appears to pose soine risk, and psychologists agree that by the time an infant is from four to five inonths old, the nother has become the irreplaceable caretaker. ${ }^{67}$

It is true that maternal deprivation studies generally have involved children whose nothers have died or children who have been removed, not only from their mothers' care, but also from other familiar household inembers and surroundings. Therefore, the risk of psychological trauma presented by other kinds of situations imvolving mother-child separation is not certain. Studies, for example, of the effects of maternal deprivation resulting from custody awards to fathers simply do not exist. It is reasonable to assume that the effects of inaternal separation would be mitigated soinewhat where a child is left in the care of a father or other adult who has participated significantly in the daily care of the child. Also, where a child has had a strong relationship with its father, the father's absence from the home may itself be a potential source of grief for the child if the mother is awarded custody.

The involvement of fathers in the day-to-day care of children is,

65. See generally S. FRAIBERG, supra note 60 , at $45-62$.

66. See 3 A. Freud \& D. Burlingham, INFANTS Without Families: Reports ON THE HaMpSTEAd NuRSERIES, THE Writings OF ANNA FreUd 182-83 (1973):

[The child's] longing for his mother becomes intolerable and throws him into states of despair which are very similar to the despair and distress shown by babies who are hungry and whose food does not appear at the accustomed time. For several hours or even for a day or two this psychological craving of the child, the "hunger" for his mother, may override all bodily sensations. There are some children . . . who will refuse to eat or sleep. Very many of them will refuse to be handled or comforted by strangers.

The children cling to some object or to some form of expression which ineans to them at that moinent memory of the material presence of the mother. Some ching to a toy which the mother has put into their hands at the moment of parting; others to some item of bedding or clothing whieh they have brought from home. Some will monotonously repeat the word by which they are used to call their nothers.

Observers seldom appreciate the depth and seriousncss of this grief of a small child. The judgment is misled for one main reason. This childish grief is short-lived. Mouming of cqual intensity in an adult person would have to run its course throughout a year, the same process in the child between 1 and 2 years will normally be over in 36 to 48 hours. It is a psychological error to conelude from this short duration that the reaction is only a superficial one and can be treated lightly.

See also 4 A. Freud, Indications for Child Analysis and Other PAPers, The Writings of ANNA FREUd (1968):

The first attempt at object love has been destroyed; the next one will not be of quite the same quality, will be more deinanding, more imtent on immediate wish fulfillment, i.e., further removed from the more inature forms of "love."

Id. at 596-97.

See generally $1 \mathrm{~J}$. BOWLBY, ATTACHMENT \& Loss (1969); 2 J. BOWLBY, ATTACHMENT \& Loss (1973); S. Fraiberg, supra note 60, at 45-62; S. PROvenCE \& R. LIPTON, INFANTS IN INSTITUtIONS (1962); Spitz, Hospitalism, 1 Psychoanalytic Study of THE Child 53, 53-74 (1945); Spitz \& Wolf, Anaclitic Depression, 2 Psychoanalytic Study of THE CHILd 313 (1946).

67. Morris, A Developmental Approach to Child Custody, 53 ConN. B.J. 330, 333 (1979). 
however, frequently minimal. ${ }^{68}$ Consequently, useful assumptions cannot be made about the extent to which the presence of the father will mitigate the effects of maternal deprivation or the extent to which absence of daily contact with the father will independently damage the child. ${ }^{69}$

However, even where the father has participated significantly in the child's daily care, existing evidence indicates that unless the father rather than the mother is the primary caregiving parent or the mother's care has been significantly deficient, there is greater disruption and risk of immediate and long range emotional damage for the child in separation from its mother than from its father. ${ }^{70} \mathrm{~A}$ child separated from its mother loses not only the security and intimacy of the affective bond with its mother, but also a familiar way of being cared for and a familiar household routine. Some discontinuity is, of course, unavoidable in virtually all cases, but a custodial award to the inother typically preserves the most continuity possible in the circumstances. The presuinption in favor of the mother therefore is consistent with the pohcy goal advocated by child developinent experts-1naximization of "continuity of care."71

68. One study of lower-, middle-, and upper-class families found that fathers typically interacted with their infants for less than one minute a day. See Rebelsky \& Hanks, Fathers' Verbal Interaction with Infants in the First Three Months of Life, 42 CHILD DEv. 63 (1971). In another study, the fathers themselves reported they spent 15 to 20 minutes a day interacting with their oneyear-olds. Independent observation of these families showed that the actual time spent was less than 38 seconds. Bau \& Lewis, Mothers and Fathers, Girls and Boys: Attachment Behavior in the One-Year-Old (April 1971) (paper presented to the Eastern Psychological Association, New York City). These findings subsequently were reported to Congress. See Hearings on American Families: Trends and Pressures, Subcommittee on Children and Youth of the Senate Labor and Public Welfare Committee, 93d Cong., 1st Sess. 147, 151 (1973) (statement of Urie Bronfenbrenner, Professor of Human Development and Family Studies, Cornell University).

69. See also the discussion infra note 92 concerning the "same sex" preference.

70. See also discussion infra note 71. See generally Morris, supra note 67.

71. See, e.g., J. Goldstein, A. Freud \& A. Solnit, Beyond THe Best INTERests of THE ChILd 31-34 (1973) [hereinafter cited as Goldstein]. Professors Goldstein, Freud, and Solnit advocate continuity of care as the guiding principle for resolving disputes between natural parents and third parties. They use the terms "biological parent" and "psychological parent" to distinguish between the biological and caregiving aspects of parenthood. In a dispute between a biological inother and foster or adoptive parents, the continuity of care standard under the best interests principle enjoins the deciding judge to place the child in the custody of its "psychological" parents-that is, adults with whoin the child has established a de facto parent-child relationshipagainst the legal claim of the inother. The preference for psychological over solely biological parents is simply a shorthand method of stating the policy goal of maintaining continuity of care. In interspousal disputes, where both claimants are at least to soine extent psychological parents, the preference for the mother is the shorthand method for stating the same policy goal. Indeed, the theoretical underpinning of the concepts of psycloological parenthood and continuity of care are in fact the studies on mother-child separation. See also S. FRAIBERG, supra note 60, at 63-77; Katz, The Maternal Preference and the Psychological Parent: Suggestions for Allocating the Burden of Proof in Custody Litigation, 53 ConN. B.J. 343, $344-47$ (1979); Leonard \& Provence, The Development of Parent-Child Relationships and the Psychological Parent, 53 CoNn. B.J. 320, 326 (1979) 
The second assumption underlying the maternal preference-that the inother (as primary caregivimg parent) will likely be better able than the father to provide the care and attention that the child needs-overlaps the first assumption in assuming that the care and attention that a child needs is principally that to which it is accustomed. The second assumption also includes, however, the notion that the inother is the nore expert caregiver. The relative caregiving skills of the parents are clearly important factors in a placement decision, and there is no better Ineans by which a judge can measure a parent's capacity or willimgness to provide primary care than his or her past performance. In the typical case, the inother's willingness and capacity to provide primary care has been demonstrated, while the father's is either speculative or clearly inferior ${ }^{72}$ Whether men and women are, as a matter of theory, equally capable of performing the mothering function has little, if any, bearing on an assumption of the mother's superior childrearing skills that are based on the consequences of the role division that the parents have themselves settled upon during their marriage.

To summarize, in the typical case where both parents are "fit" and the mother has been the primary caregiving parent, the presumption in favor of inaternal custody operates simply and sensibly to place children after divorce in the care of the parent who has had the primary responsibility for caregivimg prior to the divorce and who presumably, but for the divorce, would have continued that responsibility. In atypical cases, the presumption can be rebutted.

\section{Rebutting the Presumption}

Atypical cases fall into two categories. The first consists of those in whicli the inother is not the primary caregiving parent. Assume, for example, a custody dispute over a two-year-old child where the mother was the primary caregiving parent for the child's first year, but at the time of the proceedings has not seen the child for a year. Assume further that during the year since the separation the child has lived with its father and his female companion whoin the father intends to marry.

(mother is typically the primary "psychological" parent); Morris, supra note 67, at 326-40; Okpaku, Psychology: Impediment or Aid in Child Custody Cases?, 29 RuTGers L. Rev. 1117, 1121-22 (1976) (preference for mother maximizes continuity and is consistent with psychological theory); Watson, The Children of Armageddon: Problems of Custody Following Divorce, 21 SYRACUSE L. REv. 55, 70 (1969) (rebuttable presumption in favor of maternal custody is "psychologically sound").

72. In most instances, the father rehies not on his own caregiving skills but those of another woman, typically his mother or second wife. The availability of a competent alternative caregiver may appropriately tip the balance in favor of paternal custody where the advisability of maternal custody is already in doubt. But in the typical case, where the nother's care of and relationship with the childreu is satisfactory, the mere fact that the father can provide a substitute caregiver does not justify terminating the existing caregiving arrangement. 
Fimally, assume the female companion has taken over the child's primary care. In this situation, the policy underlying the tender years presumption does not favor maternal custody. Whatever grief and damage the child suffered because of the loss of its motler cannot be undone, and a child so young will not have any conscious memory of its mother. Disruption of the ongoing caregiving arrangement will lead only to further damage. Therefore a presumption in favor of maternal custody must be rebuttable where the mother has not been the primary caregiving parent for a significant period of time before the placement decision.

This liypothetical example illustrates why the traditional "unfitness" test is insufficiently child protective. Under the unfitness standard, the child's placement would turn, not on the child's need for continuity, but on whether the mother was "at fault" im the separation. If she had abandoned the child voluntarily, she would likely be found unfit and denied custody. ${ }^{73}$ But if she had fallen seriously ill and required prolonged hospitalization, she probably could not be found unfit and therefore would prevail. ${ }^{74}$

A similar problem would arise under the unfitness standard where the mother has never been the primary caregiving parent. If a case involved "role reversal"- -where the mother has been the primary wage earner and the father the primary caregiver-the considerations ordinarily favoring maternal custody would instead favor paternal custody. Again, however, the unfitness standard would require a court to focus on the wrong issue. Unless it was prepared to find that role reversal by itself indicated maternal unfitness, the court would have to reach a result inconsistent with the policy underlying the tender years presumption.

Under the refined doctrine contemplated here, the presumption is rebuttable on a showing that the child's immediate developmental needs would be better served by paternal custody. A father's showing that paternal custody will maximize contmuity of care would be suffcient to rebut. Thus, the refined standard eliminates the incongruity between the best interests principle and the "old" tender years doctrine, which resulted from the unfitness test's focus on the propriety of the mother's conduct rather than on the needs of the child.

The second category of atypical cases consists of those where the mother has been the primary caregiving parent, but the importance of continuity of care is outweighed by other factors. Although potentially open ended, this category is, and should remam, very narrow in prac-

73. See, e.g., Townsend v. Townsend, 358 S.W.2d 271 (Mo. Ct. App. 1962); In re Smith, 222 N.Y.S.2d 705 (Sup. Ct. 1961).

74. See Arends v. Arends, 517 P.2d 1019 (Utah 1974), cert. denied, 419 U.S. 881 (1975). 
tice. The modern view is that only those factors directly relevant to the parent-child relationship should be considered. ${ }^{75}$ Consequently, factors such as marital fault ${ }^{76}$ and adultery ${ }^{77}$ that traditionally have automatically defeated the presumption under the unfitness standard generally no longer bar custody. Apart from the fact that marital fault is itself a dymg legal and moral concept, parents experiencing difficulties between themselves often maintam good relationships with their children. Thus, even assuming that fault can be allocated to one party and that denial of custody is an appropriate sanction for marital misconduct, a marital fault rule frequently operates to punish the child as well as the parent. This practice is, of course, wholly imconsistent with the best interests principle, and its abandonment is long overdue.

The relative financial situation of the parents, on the other hand, has always been treated as largely immaterial, ${ }^{78}$ and properly so. A wealthy parent may be more likely than a less prosperous one to provide the child with material advantages, but there is no basis for assuming a correlation between wealth and good parenting or wealth and happiness. ${ }^{79}$ Moreover, the duty of support is largely independent of the right to custody. ${ }^{80}$ Therefore, any significant disparities in parental

75. See, e.g., UNIFORM MARRIAGE AND DIVORCE ACT $\$ 402$ (1973): "The court shall not consider conduct of a proposed custodian that does not affect his relationship to the child." See also cases cited infra notes 77,81, \& 82.

76. From the outset marital fault was regarded as a limitation on the tender years doctrine. See sipra note 44 and accompanyirig text. Some modern statutes still provide that the party not at fault is entitled to custody, but this entitlement is subordmate to the child's best interests. See, e.g., GA. CODE ANN. \$\$ 30-127, 74-107 (1973 \& Supp. 1980); LA. Civ. Code ANN. art. 157 (West Supp. 1975).

Professor Mnookin has commented that the marital fault rule probably resulted more frequently in custodial awards to mothers than to fathers because of the social convention that the wife filed for divorce. Mnookin, supra note 1, at 234-35. Yet a father who wanted custody of the children would not likely allow his wife to file for divorce against him simply because of social convention where he could prove fault against her. Therefore, if mothers have in fact profited historically froin the marital fault rule, the reason must be that fault was more commonly provable against husbands, that fathers did not want to contest custody, that mothers exacted custody as the cost of a divorce desired by the father, or some combination of the above.

77. Maternal adultery has traditionally been treated as per se or presumptive evidence of moral unfitness. See, e.g., Parker v. Parker, 222 Md. 69, 158 A.2d 607 (1960); Morrissey v. Morrissey, 182 Neb. 268, 154 N.W.2d 66 (1967). Recent cases indicate, however, that adultery is insuffcient to bar custody where the mother has been a good parent. See, e.g., Davis v. Davis, $280 \mathrm{Md}$. 119, 372 A.2d 231 (1971); Lockard v. Lockard, 193 Neb. 400, 227 N.W.2d 581 (1975); Commonwealth ex rel. Myers v. Myers, 468 Pa. 134, 360 A.2d 587 (1976).

Paternal adultery always has been regarded as a less serious issue. See, e.g., Hanks v. Hanks, 138 So. 2d 19 (La. Ct. App. 1962); Rex v. Greenhill, 111 Eng. Rep. 922 , 928 (K.B. 1836), discussed supra note 30 and accompanying text.

78. See, e.g., Sommers v. Sommers, 33 Wis. $2 \mathrm{~d} 22,146$ N.W.2d 428 (1966) (a contrary rule would not be "in accordance with an enlightened concept of the law").

79. See Mnookin, supra note 1 , at 284.

80. See, e.g., Sanders v. Sanders, 167 N.C. 319,83 S.E. 490 (1914); N.C. GEN. STAT. § 5013.4 (Supp. 1974). 
resources and income can generally be adjusted through the noncustodial parent's support obhgation.

Differences between parents in religious beliefs and practices ${ }^{81}$ or personal values and lifestyle ${ }^{82}$ are also generally regarded as inappropriate grounds for choosing one custodial alternative over another. Child development experts readily acknowledge their inability to pre-

81. There is no known coincidence between good parenting or healthy child development and particular religious beliefs or practices. Moreover, parents' religious beliefs are protected by the first amendment. Consequently, the general rule is that a parent cannot be denied custody solely because of his or her religion or lack thereof. See, e.g., Welker v. Welker, 24 Wis. 2d 570, 129 N.W.2d 134 (1964) (as a matter of law, mother could not be denied custody because of agnosticism). Presumably, the same reasoning applies to political behefs. But see Eaton v. Eaton, 122 N.J. 142, 191 A. 839 (1937) (mother who espoused communism denied custody), discussed in 49 HARV. L. REV. 831 (1937).

82. See, e.g., Carle v. Carle, 503 P.2d 1050 (Alaska 1972), where the trial court awarded custody of an Indian child to a mother who had moved to Juneau fron the Indian village where the father remamed. The court reasoned that the village way of life was "succumbing to the predominant, caucasian, urban society of the land" and that a young child could nore easily make the transition to the doninant culture. The Alaska Supreme Court reversed and remanded on the ground that custody should not be awarded on the "hypothesis that it is necessary to facilitate the child's adjustment to what is beheved to be the dominant culture." 503 P.2d at 1055 . See also Commonwealth ex rel. Lucas v. Kreischer, 450 Pa. 352, 299 A.2d 243 (1973) (white mother's marriage to a black man held insufficient ground for change of custody); Farmer v. Farmer, 109 Misc. 2d 137, 439 N.Y.S.2d 584 (Sup. Ct. 1981) (awarding custody to white mother over black father, holding race irrelevant). Cf. Kramer v. Kramer, 297 N.W.2d 359 (Iowa 1980) (trial court's award of custody to father because of community prejudice against white inother and black lover improper).

The inost important advance with respect to consideration of parental lifestyle is the demise of unfitness findings based on a pareut's sexual unores. In Feldman v. Feldnan, 45 A.D.2d 320, 358 N.Y.S.2d 507 (1974), for example, the court reversed a change of custody froin the niother to the father that had been based on a finding that the nother was "unfit" because of her allegedly "swinging" sex life:

[T] he evidence established that the children were well provided for both emotionally and physically ...., that the atmosphere of the mother's home was happy and cheerful ... and that the mother was sincerely concerned and devoted to the children and bestowed an abundance of love and care. In fact the [trial court] never found the mother to be "unfit," but based its decision to transfer custody on a subjective evaluation of her "life-style"....

By its decision . . . the trial court stated, in effect, that all fathers and mothers who participate in . . . "free sex" are unfit parents. The logical extension of the rationale of the trial court's position is to place the children of "swinging" couples in foster homes or orphanages.

See also Bezio v. Patenaude, [1979-1980] 6 FAM. L. REP (BNA) 2911 (Mass., Aug. 22, 1980), where the court stated a mother's sexual preference is irrelevant to her fitness for child custody. Further, the court held that the state cannot deprive parents of custody nerely because their lifestyles fail to meet the ideal of the community, and that there is insufficient evidence to support the conclusion that a lesbian household would adversely affect children's welfare.

In sharp contrast to the modern trend is Jarrett v. Jarrett, 78 Ill. 2d 337, 400 N.E.2d 421 (1979), cert. denied, 101 S. Ct. 329, rehearing denied, 101 S. Ct. 797 (1981). There the Illinois Supreme Court upheld a change of custody froin the nother to the father of three daughters, aged 7,10 , and 12 , on the sole ground that the mother's cohabitation with a man to whon she was not married was contrary to the moral standards of the state and might lead the children someday to follow her example. The change was granted despite uncontroverted evidence that the children were happy and well adjusted and that the nother was an excellent mother. 
dict, except at the extremes, how a parent's personality or a particular environment will affect a particular child's development in the long run. ${ }^{83}$ Moreover, society does not have a moral or social consensus to inform choices, except at the extremes, even between known alternatives. ${ }^{84}$ In short, most "other factors" that unight be deemed relevant to child welfare in the abstract are most often either indeterminate with respect to what is best for a particular child or too insubstantial to outweigh the known importance of providing continuity of care and of relying on time-tested caregiving skills.

Quite properly, therefore, inost denials of maternal custody arise from challenges to the mother's "fitness." If, for exainple, a mother has abused $^{85}$ or neglected ${ }^{86}$ her child or cannot provide the child with adequate care and attention, ${ }^{87}$ she typically will be found unfit and denied

83. See, e.g., Goldstein, supra note 71, at 51:

No one-and psychoanalysis creates no exception-can forecast just what experiences, what events, what changes a child, or for that matter his adult custodian, will actually encounter. Nor can anyone predict in detail how the unfolding development of a child and his family will be reflected in the long run in the child's personahty and character formation.

See also S. FrAiberg, supra note 60, at 76. See generally Freud, Child Observations and Prediction of Development: A Memorial Lecture in Honor of Ernst Kris, in 13 Psychoanalytic STUdY of THE CHILD 97-98 (1958); Mnookm, supra note 1, at 258-60.

84. See Mnookin, supra note 1 , at 260-62:

Decidimg what is best for a child poses a question no less ultimate than the purposes and values of hife itself. . . . [W] hat ... measure does a judge have [to inake such a decision] in a society that lacks a clearly defined and imtegrated set of values about what is good for particular individuals?

85. See, e.g., Howells v. Howells, 79 S.D. 480, 113 N.W.2d 533 (1962).

86. See, e.g., Bennett v. Bennett, 146 So. 2 d 588 (Fla. Dist. Ct. App. 1962); Valentine v. Valentine, 203 S.W.2d 693 (Tex. Civ. App. 1947); Storgaard v. Storgaard, 26 Wash. 2d 388, 174 P.2d 309 (1946). Cf. Vehle v. Vehle, 259 S.W.2d 229 (Tex. Civ. App. 1953) (custody award to father reversed when father neglectful and irresponsible in providing care).

87. Mothers are inost commonly found unable to provide appropriate care because of unental illness or "einotional instabihty." See, e.g., Knox v. Knox, 226 Ga. 619, 176 S.E.2d 712 (1970); Corcoran v. Corcoran, 79 Ill. App. 2d 328, 224 N.E.2d 611 (1967); Andreesen v. Andreesen, 252 Iowa 1152, 110 N.W.2d 275 (1961). Most courts require a showing that the mother's inental illness or eunotional problems affect her capacity to provide care or in some way threaten harm to the children. See, e.g., Commonwealth v. Bender, 197 Pa. Super. 397, 178 A.2d 779 (1962). But some courts have demed custody to the mother even where no evidence indicates that the mother's emotional problems interfere with her caregiving. In Masek v. Masek, 89 S.D. 62, 228 N.W.2d 334 (1975), discussed supra note 56, for example, the trial judge found the mother "unsuitable" for custody in part because of "emotional problems" that led her to "drink excessively." The mother's psychiatrist testified that the emotional problems were related to the breakdown of the inarriage itself and that the drinking was a temporary rcaction to situational stress. Moreover, the "excessive" drinking consisted of having been intoxicated "perhaps" once or twice in her own hoine. Nothing in the record suggested that the mother had at any time been anything but a loving and conscientious parent.

The danger inherent in inquiries into a parent's emotional stability and in psychological profiles is that they will become disguised inquiries into parental values and lifestyles. A court might, for example, acknowledge that adultery is not a proper ground for refusing a parent custody, but conclude that the parent's adulterous conduct indicates neurotic tendencies that would make such a parent unfit for custody. Therefore, findings of instability should be supported by 
custody.

Nevertheless, the unfitness standard is unsatisfactory as the general standard of rebuttal, even where the mother has been the primary caregivimg parent. First, paternal custody sometimes may be better for the child even though the mother is not unfit im any way. For example, a child may have a demonstrably closer and stronger relationship with its father. Second, maternal custody sometimes may be better for the child despite the mother's allegedly unfit conduct-for example, where a child is strongly attached to, and adequately cared for by, a mother with a drinking or emotional problem. The inquiry must always focus on, not whether the mother has im some way forfeited her claim to custody, but whether the detriment allegedly attached to maternal custody or the benefit allegedly attached to paternal custody is sufficiently nonspeculative and important to justify the known harm of disruptimg the ongoimg caregiving relationship.

The presumption that maternal custody is best for a child, absent an evidentiary showing that paternal custody better serves the child's developmental needs, preserves the proper inquiry. It emphasizes that the process is weighing alternatives for the child, not conductimg a personality or fitness contest between the parents or giving rein to the social and moral biases of individual judges. Of course, no set of guidelines can protect agamst honest errors in close cases. But the rebuttable tender years-presumption clearly sets practicable guidelines consistent with sound child welfare and the best interests principle for decisionmaking in atypical cases as well as typical cases.

\section{The Scope of the Tender Years}

A final consideration with respect to the operation of the tender years presumption is the scope of its application. Historically, the term "tender years" was used in English law to describe children too young to exercise their own discretion in choosing a guardian. ${ }^{88}$ In guardianship law, the age of discietion typically is set at fourteen. ${ }^{89}$ In this country, the tender years have been defined only vaguely as ending approximately at the onset of adolescence. ${ }^{90}$ As a practical matter,

testimony of psychiatric experts. Moreover, expert testimony on a parent's mental state should be relied on only where the expert actually has examined the parent, which is not always the case. See, e.g., Vishnevsky v. Vishnevsky, 11 Wis. 2d 259, 105 N.W.2d 314 (1960), discussed in Okpaku, supra note 71 , at $1147-49$.

88. See Rex v. Greenhill, 111 Eng. Rep. 922 (K.B. 1836).

89. See, eg., Mich. CoMp. LAws ANN. $\$ 703.3$ (1968).

90. See, e.g., OKLA. Stat. ANN. tit. 30, § 11 (West 1955):

As between parents adversely claiming the custody or guardianship, neither parent is entitled to it as of right, but, other things being equal, if the child is of tender years, it should be given to the mother; if it be of an age to require education and preparation for labor or busmess, then to the father. 
however, most interspousal custody disputes involve children under the age of nine. They rarely include children over eleven or twelve, presumably because these children can make their own preferences known. Thus even a wholly arbitrary confinement of the tender years doctrine to children under thirteen or fourteen would have virtually no impact on interspousal custody disputes. The question remains, however, whether a more precise definition-and specifically an age limitation short of adolescence-should be adopted. My answer is no.

Four factors determine the scope of the tender years. The first two factors are centrism (the degree to which the child's life is centered around its mother) and dependency (the degree to which the child is dependent on its mother). The case for maternal custody typically is more compelling for very young children than for older children because of these two factors. The world of a five-year-old, for example is ordinarily more centered around its mother and the daily caregiving routine than is the world of a ten-year-old. A five-year-old is ordinarily more dependent on direct physical care than is a ten year old. Loss of the mother's daily care is therefore likely to be more disruptive for a five-year-old.

But children vary considerably im their individual rates of development. Some ten-year-olds are more mother-centered and dependent than some five-year-olds. Moreover, children do not develop along a steady contimuum from dependency to independence. Rather, periods of imcreased independence can alternate with periods during which the child becomes very mother-centered again. ${ }^{91}$ Consequently, a given child might be more damaged by separation from its mother at ten than at nine. Finally, the values protected by the tender years presumption do not lose their validity at any particular chronological age. Even a very independent ten-year-old is still a child, still im need of caregiving, still in need of contimuity of care. Since the importance of centrism and dependency varies among children of the same age and within the same child at different stages of development, placing a specific age limit on the tender years presumption short of adolescence would be psychologically unsound.92

91. See generally A. Gessell \& F. Ilg, The Child From Five to Ten (1946) \& The Child FROM TEN TO FIFTEEN (1946).

92. Cf. Morris, supra note 67 (importance of mother-child relationship generally outweighs all other considerations through preadolescence). Two commentators have suggested a specific age limit on the tender years presumption for male children. See Bradbrook, The Relevance of Psychological and Psychiatric Studies to the Future Development of the Laws Governing the Setllement of Inter-parental Chiid Custody Disputes, 11 J. FAM. L. 557 (1971) (age 7); Watson, supra note 71 (age 10). The assumption underlymg this proposed limitation is that older boys ordinarily have greater need for daily contact with the father as a role model than with the mother as a caregiver. The Iowa Supreme Court recently reversed a custodial award to a father predicated on such an assumption as an impermissible gender-based preference. Tresnak v. Tresnak, [1979-1980] 6 
On the other hand, as children grow older and other considerations are given unore weight, the policy underlying the tender years presuinption may lose some strength. Consider, for example, two custody cases. In both, the nother who has been the primary caregiver intends to inove to California after the divorce, while the father intends to stay in the family hoine in Kansas. In the first case, the child is five; in the second, the child is ten. Maternal custody is almost certainly the less disruptive choice for the five-year-old, but it may be the inore disruptive choice for the ten-year-old if the child's routine and social attachinents are strongly centered around school and the father has been significantly involved in the child's care.

The second two factors underlying the concept of the tender years are the child's need for a proxy decisionmaker and the court's assessment of the child's capacity to determine its own best interests. Whether children of any age should ever be asked to choose between parents is a question beyond the scope of this analysis. ${ }^{93}$ As a practical matter, however, the overwhelming majority of children im interspousal disputes are clearly too young to coinprehend or be burdened by such a decision while many older children are unwilling to state a preference. These children (even those older than fourteen) are of tender years im the historical sense because they are dependent on the court to act on and in their behalf as a proxy decisionmaker. On the other hand, where a child voluntarily expresses a preference and the judge is persuaded that the child is sufficiently inature to understand his situation and the consequences of his choice, considerable, if not decisive, weight should be given to the child's preference. ${ }^{94}$ In this situation, the child's preference is not "rebutting" or outweighing the tender years presumption. Rather, the presumption that inaternal custody will best protect the child's welfare need never be invoked because the child has been found competent to adjudge his own self-interest. In short, he can no longer be considered of tender years.

Apart, however, from the situation in which a mature child voices his own choice, age and inaturity go only to the weight to be accorded the tender years presumption relative to other factors, not to the valid-

FAM. L. REP. (BNA) 2892 (Iowa, Sept. 17, 1980). In contrast to the consensus favoring continuity of care as the predominant developmental need, there is presently no consensus among psychological theorists on the role of the same-sex parent in sexual identification. See Okpaku, supra note 71, at 1127. Moreover, no empirical evidence supports the assumption that children raised solely or primarily by an opposite-sex parent are by virtue of that fact more prone to psychosexual difficulties than children raised solely or primarily by a same-sex parent.

93. Some problems involved in eliciting a child's preference are surveyed in Siegel \& Hurley, The Role of the Child's Preference in Custody Proceedings, 11 FAM. L.Q. 1 (1977).

94. For a sensitive handling of a young child's expressed preference, see Goldstem v. Goldstein, 115 R.I. 152, 341 A.2d 51 (1975). 
ity of its underlymg assumptions. Accordingly, a specific age limitation on the presumption short of adolescence would be wholly arbitrary and therefore unwise.

\section{B. The Alternatives}

Critics have suggested two alternatives to the tender years doctrine favoring maternal custody. The first is to choose the custodial parent under a discretionary best interests test. The second is to choose the custodial parent by a state administered lottery or com flip. Supporters argue that each approach is inore consistent with equal parental rights in children than is the tender years presumption. However, neither alternative is as child protective as the tender years presuinptive rule. ${ }^{95}$

\section{The "Best Interests" Test}

Most critics of the tender years presumption advocate the adoption of a systein under which the deciding judge determines what is best for a particular child on the facts of the case without reference to any presumptive rules. The arguments advanced in support of this approach are essentially negative. First, critics contend that the tender years presumption is inherently invahid, ${ }^{96}$ an argument which the foregoing analysis shows is erroneous. Second, critics argue that presumptive rules such as the maternal preference interfere with the judicial factfinding necessary to make an individualized deternination of what is best for the child. ${ }^{97}$

This second argument would be persuasive if the presumption in favor of maternal custody were irrebuttable. It also might be persuasive if the standard for rebuttal were too narrow to be child-protective. But a presumption in favor of inaternal custody that is rebuttable on a showing that an alternative disposition would better protect the child's developmental needs does not interfere with judicial inquiry. The competing parents still are free to present as much lay and expert testi-

95. Interestingly, the most obvious alternative to the tender years doctrine-a gender-neutral presumption in favor of the primary caregiving parent-has never been proposed by any critic of the gender-specific presumption. The reason may well be that a gender-neutral presumption would have no appreciable effect on the number of custody awards to fathers, because the mother, in the overwhelming inajority of cases, is the primary caregiving parent. This in turn suggests that critics of the tender years doctrine are principally concerned with promoting a more equal distribution of custody awards between parents and not with ehminating impernissible gender-specific classifications. As the preceding analysis shows, however, more equal distribution of custody is not supportable as a matter of child-welfare pohicy and is therefore inconsistent with the principle that the interests of children are paramount to the interests of the competing parents. Whether the tender years presumption must as a matter of constitutional law be expresscd as a gender-neutral rule favoring the primary caregiving parent is, as noted earlier, discusscd infra Part III.

96. See supra notes 10-11 and accompanying text.

97. See, e.g., Foster \& Freed, supra note 8, at 341. 
mony as their resources permit. In addition, the judge can or must enlist assistance from court-appointed social workers or guardians ad litem. The role of the presumption is not to limit inquiry, but to focus it by settimg the standards for decisionmaking. The presumption does not eliminate judicial discretion; it guides it. All decisionmaking is necessarily based on presumptions-either those of the individual decisionmaker or those set by law. Thus, as long as the tender years presumption is sound, which it is, and the standard for rebuttal sufficiently child protective, which it is, the use of the presumption is a legitimate jurisprudential device to facilitate decisionmaking and protect agamst ad hoc lawmaking.

When the argument against the legitimacy of presumptive rules generally and the tender years presumption in particular is removed, the case for discretionary adjudication evaporates. As a principle of law, the best interests standard means only that the welfare of the child is paramount to the interests of the parents. As a substantive test for decisionmaking, the phrase lias no meaning other than that which the state legislatures and courts give it. If defining standards are not provided, the test is simply a grant of broad discretion to trial judges to exercise their own views on what is best for children. Such a system has obvious jurisprudential shortcomings. If every judge were at hiberty to determine what would be best for a child, then no case would have precedential value. Like cases could be decided differently, not only in different courts, but in the same court, and parents would have no notice of the standards used to judge them. Moreover, parents denied custody would have no recourse to ineaningful appellate review. The standard of review in custody law is generally abuse of discretion, and broad discretion cannot easily be abused.

Wholly discretionary decisionmaking without the safeguard of appellate review clearly does not better serve the interests of children than does the tender years presumption favoring the mother. The discretionary best interests test would increase the risk of decisions inconsistent with current knowledge of the developmental needs of children. It also could lead to more decisions based on value biases against, for example, unconventional lifestyles. At the same time, the lack of recourse to effective review would virtually eliminate the opportunity to correct sucl nnistakes or to prevent them in subsequent cases. In addition, the uncertainty engendered by the discretionary best interests standard unay encourage litigation and increase delays in settling custody disputes. ${ }^{98}$ These byproducts of the discretionary approach raise

98. The combination of the abandonment of marital fault standards for divorce and the adoption of broad discretionary standards for child placement may create an invitation to divorcing spouses to use custody battles as a forum for venting residual anger and bitterness. 
serious questions, not only of judicial economy, but of child welfare. Custody battles and uncertainty about their futures are detrimental to children.99 Ad hoc adjudication would therefore introduce serious threats to institutional imtegrity and undermme the child-protective policy of the best interests primciple in the pursuit of results that are unpredictable and im the case of error not easily corrected.

\section{The Lottery}

The second suggested alternative to the tender years presumption is to choose the parent by the flip of a coin. The authors of Beyond the Best Interests of the Child originally suggested this approacli as an alternative to ad hoc adjudication under the best interests test. ${ }^{100}$ In comparison, the coin flip has some appeal. Both systems are ultimately arbitrary, but the coin flip has the virtue of being openly and impersonally so. It might also be quicker and cheaper. Professor Mnookin has observed, lowever, that the coin flip may not be a realistic alternative because most people would find the system offensive. ${ }^{101}$

Determining the point at which the coin should be flipped presents a more fundamental analytic difficulty. If the object of a lottery is to give parents an equal chance at prevailing, then no judicial proceedings are necessary. If, however, the object is to serve child welfare, the coin flip inust be preceded by some judicial determination that neither custodial alternative is preferable. Indeed, Professors Goldstein, Freud, and Solnit intended the lottery only as a tie breaker between parents "equally suitable in terms of the child's most immediate predictable needs." 102 But what standard should govern this determination? If a judge must determine when a tie breaker is necessary, the lottery approach involves all the probleins of ad hoc adjudication. Moreover, it rarely will be invoked because soine reason can alniost always be found for preferring one parent. Assuming that the most immediate predictable need of children is inaximization of continuity of care-an assumption encompassed by the tender years presumption and espoused by the authors who proposed the com flip alternative ${ }^{103}$ - the coin flip would only be used in cases imvolving two equally caregiving parents. Such situations are likely to arise only rarely because caregiving responsibilities usually are not distributed equally between parents. Furthermore, parents who have in fact achieved a high degree of cooperation and sharing during their narriage are likely to reach

99. See GoldSTEIN, supra note 71 , at $40-45$.

100. Id. at 63 n.12.

101. Mnookin, supra note 1, at 290-91.

102. GoldSTEIN, supra note 71, at 63.

103. See supra note 71 . 
agreement over custodial arrangements privately or be appropriate candidates for joimt custody. Thus the coin flip at best has limited use m a system based primarily on other decisional criteria.

If the legislatures and courts adopt ineaningful substantive guidelines under the best interests test that are based on our existing understanding of child developinent-a primary caregiving parent presumption, for example-the resulting system will be functionally equivalent to the rebuttable tender years presumption. ${ }^{104}$ Different presumptions could, of course be adopted. But so far none has been suggested, and, as already discussed, most factors beyond continuity of care are widely recognized to be indeterminate with respect to what is best for a given child. ${ }^{105}$ Thus a different set of presumptions would produce only different, not inore child-protective, results.

In summary, the only genuine alternative to the rebuttable tender years presumption favoring maternal custody (or a functional equivalent, such as the primary caregiver presumption) is ad hoc adjudication, a system that is jurisprudentially offensive and demonstrably less child protective than the presumption. Abandonment of the presumption in favor of ad hoc adjudication is therefore inconsistent with the principle that the paramount concern of the law in custody disputes is the welfare of the child.

\section{III \\ Constitutional Questions}

The previous sections have defended a rebuttable tender years presumption in favor of maternal custody as sound child-welfare pohicy. We now turn to the question of its constitutionality. The most farreaching decision on this issue is Watts $v$. Watts, ${ }^{106}$ in which Judge Kooper of the New York Family Court concluded that a presumptive preference for maternal custody, "other things being equal"-a presumption equivalent to the rebuttable tender years presumption defined earlier ${ }^{107}$-violates the father's rights to equal protection under the fourteenth amendment. ${ }^{108}$ Judge Kooper concluded that snch a

104. See supra note 95; supra text accompanying note 71. A presumption in favor of the parent whose custody would maximize continuity is a somewhat awkward expression for the primary caregiving presumption.

105. See supra text accompanying notes 78-87.

106. 77 Misc. 2d 178, 350 N.Y.S.2d 285 (Fam. Ct. 1973).

107. See supra note 49. As discussed earher, supra note 10, the Alabama Supreme Court has held that the traditional tender years presumption, rebuttable only by a showing of the mother's unfitness, violates the 14th amendment. Because the unfitness rebuttal standard is insufficiently child protective, see supra notes 73-87 and accompanying text, the traditional doctrine should be modified to conform with existing understandings of the developinental needs of children. Therefore, this Article does not address its constitutionality.

108. Custody was awarded to the father on the grounds that this disposition best served the 
presumptive preference could not be justified by the state's "compelling" interest im protecting the best interests of the child because (1) "[t]he simple fact of being a inother does not, by itself, indicate a willingness or capacity to render a quality of care different from that which the father can provide" 109 and (2) child development studies indicate that the "essential experience for the child is that of mothering," not the gender of the person performing the mothering function. ${ }^{110}$

The threshold fiaw in the Watts analysis is that it fails to distinguish between two very different questions. The first, to which Judge Kooper's supporting argument is addressed, is whether a inother may ever be preferred under the best interest primciple solely because of her gender or her biological motherhood; in short, whether feinalenessbiological inotherhood-is itself sufficiently relevant to a child's welfare to justify a gender-based maternal preference. The second question, which Judge Kooper purportedly decided, but in fact never addressed, is whether a preference based, not on gender, but on continuity of care ("the essential experience of mothering") inay be expressed as a preference for inothers; ${ }^{111}$ that is, whether gender is a sufficiently reliable proxy for primary caregiving parents to justify use of a gender-specific maternal preference presuinption rather than, for example, a gender-neutral primary caregiving parent presumption. This second question was answered affirmatively by the Oklahoma Supreme Court in upholding that state's statutory preference for maternal custody "other things being equal." 12

This section argues that, contrary to Watts, the answer to the first question is yes and that the answer to the second question, while probably yes, is of no practical importance.

\section{A. The Permissibility of a Gender-Based Maternal Preference}

\section{Relevancy}

In Watts, Judge Kooper found that a maternal preference presumption does not serve the best interests of children because gender is

interests of the children. Unfortunately, the opinion does not state the facts of the case or explain the basis for the decision.

109. 77 Misc. at 181,350 N.Y.S.2d at 289.

110. 77 Misc. at 182,350 N.Y.S.2d at 290.

111. This failure to identify and analyze the issues properly is not unique to the Watts opinion. Courts that have held the maternal preference violative of state law provisions outlawing gender-based discrimination have invariably failed to distinguish between a placement decision based wholly on gender and a gender-specific presumption based on mothering. Courts that have unade the distinction and upheld the continuing viability of the preference have not addressed the permissibihty of a gender-specific nothering-based presumption. See cases cited supra note 10.

112. Gordon v. Gordon, 577 P.2d 1271, 1277 (Okla.), cert. denied, 439 U.S. 863 (1978). 
irrelevant to the capacity and willingness to perform the mothering function and to the child's experience of mothering. To test this argument, assume that a mother and father separate during the mother's pregnancy and the father seeks custody effective at the child's birth. Assume further that the state accords no special deference to the mother's interest in nurturing the child, 113 that both parents are "fit," and that the judge recognizes that mothering is the essential experience

113. The Watts analysis is predicated on the assumption that the apphicable state law requires strict neutrahity with respect to parental interests in children. This Article is mamly concerned with defending the tender years presumption as sound child welfare policy and so for the purposes of testing the logic of Watts accepts the same starting premise. Whether absolute neutrality is in all circumstances sound policy and whether absolute neutrality is constitutionally compelled, however, are very different questions. Parental rights are not property rights. They derive from a fundainental liberty interest in reproduction and childrearing. Thus, while the mdividuals who biologically produce a child may automatically acquire parental rights im the child, it does not necessarily follow that male and female parents should automatically be recognized as having the same rights and interests in all circumstances.

In the hypothetical dispute over the newborn baby, for example, the mother-child and fatherchild relationships are very different. The father's relationship to the clild is at this poimt wholly genetic. The mother has a precisely equal genetic relationship to the child, but in addition has estabhshed an intiunate physical relationship. Moreover, slie has undergone significant physiological and psychological changes that may well make her attachment to the child and her desire to mother the child compelling. Insistence on a policy of neutrality in this situation requires us to ignore the mother's obviously different and greater involveinent in the procreative process. Yet to ignore the differences is to ignore what is a very real and umiquely female need to mother, the frustration of which may cause serious damage to the mother's psychological and physical health. A pohcy of ignoring the consequences of a uniquely feminine experience solely because it is uniquely feminine has little to recounmend it. Similarly the notion that it is somehow unfair to fathers to recognize a mother's paramount right to be the primary caregiver of her newborn offspring is tantamount to arguing that it is unfair that fathers cannot bear children.

How permissible - or necessary-it is to recognize different interests in male and female parents because of their different procreative functions is very much an open question. In Planned Parenthood v. Danforth, 428 U.S. 52, 67-75 (1976), the Supreine Court held that a state could not constitutionally condition a woman's right to terminate an unwanted pregnancy on the consent of lier husband. In so doing, the Court declined to recognize any paternal mterest in the fetus. In his concurring opinion, Justice Stewart took the more persuasive position. He recognized that the father lias an interest in his child-to-be, but since only the mterests of either the inother or father could prevail, the father's interest must be subordinated to the mother's because of her greater involvement in the procreative process. Id. at 90 (Stewart, J., concurring). One implication of Danforth is that "preferential" treatment of female parents because of their reproductive function may be required in other contexts as well. See also Dike v. School Bd. of Orange County, Fla., 650 F.2d 783 (5th Cir. 1981) (holding that a public school's refusal to allow a teacher to breastfeed her child during nonduty time of school days would, unless necessary to effectuate important state interests, violate the woman's constitutionally protected right to breastfeed). In addition, the Court has held that a gender-based classification is not "invidious" discrimmation where it "realistically refiects the fact that the sexes are not similarly situated." See Rostker v. Goldberg, 101 S. Ct. 2646, 2659 (1981) (quoting Michael M. v. Superior Court, 101 S. Ct. 1200, 1204 (1981) (upholding gender-based "statutory rape" statute). See generally Caban v. Mohammed, 441 U.S. 380, 404-14 (1979) (Stevens, J., dissenting).

Thus, while this Article's principal argument is that a gender-based preference for maternal custody of a newborn or very young child is justifiable solely in terns of the child's welfare, it also recognizes that a preferential entitlement to custody for inothers of very young children, subject to protection of the child's interests, is both consistent with the best interest principle and constitu- 
for the child. Should the judge in this situation ignore the facts of biological motherhood and gender? Would the best interests of the infant be served by assuming that the parents are equally capable of perfornmg the mothering function and that a coin flip should determine custody? Surely not.

To begm with the obvious, the mother might intend to breastfeed the baby. ${ }^{114}$ Simce there is a virtually coinplete consensus among doctors and psychologists that breastfeeding is better for the baby's physical health and enhances the mothcring experience for the child, ${ }^{115}$ a court could not ignore the fact of biological inotherhood and award custody on gender-neutral principles.

Second, we do not in fact know the extent to which biological motherhood or the capacity to bear children affects the capacity and willingness to provide inothering. Judge Kooper states that "[e]minent psychologists and anthropologists, including Margaret Mead, have . . . asserted that inothers and fathers are equally able to ... perforin childrearing functions." 116 To support this statement, she cites a passage from an article in which Dr. Mead argued (1) that mother-child separation of even a few days will not dainage the child and (2) that there is no noncultural reason why fathers could not participate more equally in the childrearing process. ${ }^{117}$ The first proposition is essentially a defense of wage earning inothers. ${ }^{118}$ The second proposition does not support a conclusion that inen are now as capable as woinen to perforn the inothering function, nor does it deny the possibility of a biological connection between gender and the willingness and capacity to undertake the primary care of infants and young children. Dr. Mead has, in fact, written elsewhere and far inore recently that "[w]e do not know whether the fact that woinen's bodies are prepared to bear children inay not also be a crucial determinant of certain aspects of behavior traditionally regarded as feminine." 119

tionally justified by an independent state interest in protecting the mother's need, if not right, to mother the child she has borne.

114. The National Center for Health Statistics reports that in 1981, 55.3\% of mothers breastfed their infants (up from $24.7 \%$ in 1971), and $25 \%$ of the mothers breastfed their infants six inonths or longer (up from 5.5\% in 1971). Chicago Sun Times, Jan. 31, 1982, at 20, col. 1.

115. See M. Walker, B. Yoffee \& P. Gray, The Complete Book of Birth 213-22 (1979).

116. 77 Misc. at 182,350 N.Y.S.2d at 289.

117. Mead, Some Theoretical Considerations on the Problems of Mother-Child Separation, 24 AM. J. ORTHOPSYCHIATRY 471, 477 (1954).

118. The article was written in 1954 , when it was widely believed that any separation from the mother would permanently damage the child. The court pointed out that Dr. Mead asserted that the insistence on the need to avoid any separation was a "subtle form of anti-feminism." 77 Misc. at 182,350 N.Y.S.2d at 289.

119. Mead, On Freud's View of Female Psychology, in Women \& ANALYsis 95, 104-05 (J. Strouse ed. 1974). Erik Erikson has expressed the view that men "can partake of notherliness-if permitted to do so by powerful inores." Erikson, Womanhood and the Inner Space, in id. at 312. 
Given the absolute helplessness and long duration of human infancy, it is virtually untenable from the viewpoint of evolutionary biology that the survival of an infant could depend solely on anything so fragile as social convention. ${ }^{120}$ Because, however, a woman's preparation for motherhood, whether she ultimately becomes a mother or not, is so pervasively reinforced by cultural forces in all societies, it has been impossible to determine to what extent maternal behavior is biologically dictated and to what extent it is socially conditioned. ${ }^{121}$ Nor do we know the extent to which existimg gender-specific differences im behavioral responses to infants can be equalized or reversed. ${ }^{122}$ Two possible biological obstacles to socializing men to perform the mothering function may be the absence of a biological impetus, which animal experiments suggest may be related to female hormones, ${ }^{123}$ and the imcompatibility of maternal behavior and aggression, which is linked to the male hormone androgen. ${ }^{124}$ In any event, absent a concerted effort both to socialize men to be primary caregivers and to socialize women not to be primary caregivers, biological and cultural factors will continue to coinbime to prepare women for infant rearing in a way that men simply are not. The fact, then, that mothering is not wholly gender-neutral undercuts Judge Kooper's assertion in Watts that gender is irrelevant to the capacity or willingness to perform the mothering function.

Judge Kooper's assertion that biological motherhood and gender are irrelevant to the child's experience of mothering is also without foundation. None of the authorities cited for this assertion even dis-

Erikson insists however that the anatomically based psychological orientation of the sexes is such that mothering is the uniquely creative function of women, quickly adding, however, that "no woman hives or needs to hive only in this extended somatic sphere." Id. at 315 . See generally Erikson, Once More the Inner Space, in id. at 320.

120. See Erickson, Once More the Inner Space, supra note 119, at 336:

True, we can see now-now that we can avoid it technologically-how motherhood was used to enslave women by the combimed forces of instinctual drive, social tradition, and inner collusion. But, again, the mere attempt to right a wrong by turning it upside down and to clain that there is no instimctual need for parenthood and that parenthood is nothing but social convention and coercion will not liberate anybody's choices.

121. D. Stern, The First Relationship 28 (1977).

122. Mothers typically demonstrate extraordmary sensitivity and attentiveness to the nuances of their infants' behavior. See R. SPITz, supra note 60, at 127, 133-38. Moreover, women respond more readily than do men to infants and to "babyness" both in the laboratory and in daily life, and they generally have a "more extensive and richer repertoire of infant-elicited social behaviors" that manifests itself by puberty. D. STERN, supra note 121 , at 28 . We are wholly ignorant of the extent to which, and at what cost, such behaviors can be suppressed in women and induced in men. Id.

123. See Moltz, Lubin, Leon \& Numan, Hormonal Induction of Maternal Behavior in the Overiectomized Nulliporous Rat, 5 PHYSIOLOGY \& BEHAVIOR 1373 (1970); Rosenblatt, The Development of Maternal Responsiveness in the Rat, 39 AM. J. ORTHOPSYCHIATRY 36 (1969).

124. See, e.g., E. Maccoby \& C. Jacklin, The Psychology of SeX Differences $242-47$ (1974). 
cusses the relationship between gender and the mothering experience, much less denies a connection. ${ }^{25}$ Moreover, empirical evidence suggests a contrary conclusion. For example, a "sensitive" period for mother-infant bonding during the first hours and days after birth has been well documented. ${ }^{126}$ Also, an infant's attachment to its mother may begin in utero. A pregnant woman is, to use an old-fashioned phrase, "with child," and the two are bound together for the better part of a year in an intimacy unparalleled elsewhere in human experience:

At this point it is only speculation in pediatrics, but we think that the baby . . . is preparing for attachment before birth. An infant in utero can hear. Sounds get through; the fetus responds to sound; and the mother's voice transmits readily through the diaphragm. The infant in utero becomes used to some aspects of his mother: her voice, heart rate, sleep-wake cycle, and her various moods. Obviously, then, the baby is not going to have to come out and start anew. He has a good idea of what his inother is like already and is prepared to attach to this familiar person. ${ }^{127}$

Consequently, a child may bond principally to its mother, and thus feel the essential experience of inothering through her, even where othcr persons, includimg the father, have a significant or even equal role im caregiving.

In addition, there may be subtle differences, both qualitative and quantitative, in the way inothers and fathers (or more generally women and men) interact and communicate with infants that appreciably affect the quahity of a child's inothering experience and therefore its social development. ${ }^{128}$ Finally, there inay be important developmental and psychosexual reasons not yet understood why children, both male and female, are biologically intended to experience their first intimate attachment to, and identify with, a woman.

Thus while soineone other than the mother can (mdeed must, if the child is to survive) perform the mothering function where the inother is not available, it does not necessarily follow that the child's experience of mothering and its future development will not be affected by whether the mother or some other adult provides the mothering. Our profound ignorance about the life process and about human bonding argues strongly agamst proclanning a brave new world of childrearing detached from biological foundations. Given our meager knowledge, such a proclamation would subordmate child welfare to

125. Spitz \& Wolf, supra note 66; Yarrow, Maternal Deprivation: Toward an Empirical and Conceptual Reevaluation, in Psychological Bulletin 58 (1961).

126. M. KLAUS \& J. KENNELL, supra note 57.

127. Dr. Constance H. Keefer, expert on mother-infant bonding at Children's Hospital Medical Center of Boston, quoted in M. WALKER, B. YOFFEE \& P. GRAY, supra note 115, at 230.

128. See generally, e.g., R. Spitz, supra note 60 , at $122-49$. 
ideology, if not politics. The bottom line on existing research is that the biologically given pattern of infant rearing is optimally designed to meet the existential and developmental needs of children and that the further removed from this pattern the child's experience is, the greater the risk that the child's capacity to fulfill its human potential will be diminished. ${ }^{129}$ The prudent view, the child-protective view, in these circumstances is suggested by Margaret Mead:

Although it is possible to demonstrate that the social definition of male and female roles throughout prehistory and history have reflected practical conditions . . . there are many unanswered questions. . . .

We live in a period of time when much of human behavior has been seen as a nuisance to be eliminated-mechanically, biochemically, chemically. . . . And we are almost completely ignorant of what the consequences of such mtervention in very anciently biologically given sex differences may be. These are areas in which Freud's dictumanatomy is destiny-must be kept in mind. We might easily choose a course that in its emphasis on artificial intervention in natural processes transforms human beings into beings who are incapable of the primary love and loyalty for kith and kin and country necessary for survival. . . .

The path Freud outlined, although in his discussion of the psychology of women he was completely culture-bound, still suggests that the rhythms of human development, patterned during a million years, are ignored at our peril, and understood, give us wisdom. ${ }^{130}$

\section{Weight}

To return to the hypothetical custody case, assume that the judge awards custody of the newborn to its mother and that the deterininative factor is that the mother is the female parent. Is this, again presummg neutrality with respect to the parents' interests, ${ }^{131}$ violative of the father's equal protection rights? Under the test set forth in Craig v. Bo$r e n,{ }^{132}$ a gender-centered classification must bear a substantial relationship to an inportant governmental objective, "substantial relationship" meaning a substantial congruence in fact between gender and the characteristic that gender purportedly represents. Promoting the welfare of children in the resolution of custody disputes is obviously an important, indeed a "compelling," governmental objective. Scientific evidence establishes that inothering is an essential experience for children, that the capacity to bear children is relevant to an unknown degree to the capacity and willingness to perforn the inothering function,

129. See generally S. FRAlBERG, supra note 60, at 33-62.

130. Mead, supra note 119 , at 105 .

131. See supra note 113 .

132. 429 U.S. 190 (1976). 
and that gender is relevant to the enhancement of the child's mothering experience and the formation of strong human bonds. Here the assumed congruence is between being female and the capacity to bear children, a congruence that is immutably complete. Thus, a genderbased maternal preference may be justified on the ground that it serves the state's imterest in promotimg the welfare of children. However, a preference for the mother, solely because she is the mother, will still face constitutional problems if too much weight is accorded biological motherhood.

Suppose, for example, a woman bears a child, leaves it immediately in the father's care, and then returns some years later to claim the child. An award to the mother based solely on her biological motherhood would give disproportionate weight to whatever benefits might still attach to the biological nother-child relationship as compared to the benefits of preserving the child's ongoing custodial arrangement. Similarly, a custodial award to a mother because she is the mother, even though she has physically abused her children, would give disproportionate weight to the biological relationship relative to the immediate threat to the children's well-being. In both cases, a gender-based preference for the mother would be unsound child-welfare policy and therefore arguably unconstitutional under the substantial relationship test.

A maternal custody award in the hypothesized case of the newborn child where both parents are fit, however, presents a very different situation. One way of looking at the maternal preference in this circumstance is to regard it as an uncommon apphication of the preference for the primary caregiving parent. Although neither parent has assumed the role of caregiver with respect to the child outside the womb, the mother has nurtured the child and established both a physical and psychological relationship with it during pregnancy while the father has not and could not. Alternatively, the gender-based preference in the hypothetical can be regarded as a tie breaker between two otherwise equally fit parents. The question then becomes whether there is a more child-protective tie-breaking device. The maternal preference is clearly more child-protective than the lottery, which is the only other tie-breaking device suggested so far. If further research were to prove that it does not matter whether a child is mothered by its own mother or by someone else, then both the lottery and the maternal preference will have produced sound results $100 \%$ of the time. If, however, further research confirms the present evidence that mother-child separation diminishes the child's experience of love and security, the maternal preference will still have produced sound results $100 \%$ of the time while the lottery will have produced sound results only $50 \%$ of the time. 
The same reasoning applies equally to other tie-breaking situations involving children beyond infancy in which a choice must be made between otherwise equally fit parents. If, for example, botli parents have shared so fully in the daily care of their child that neither can be identified as the primary caregiving parent (and joint custody is not feasible), then the use of a gender-based maternal preference, at least for very young children, is still more child protective than a lottery. A lottery necessarily assumes that everytling is equal. The inaternal preference assumes that all things are not, or may not be, equal because the mother has had a longer and more intimate relationship with the child. The subtle, but important benefits that the mother-child relationship may provide for the child cannot be ignored in a system truly committed to the welfare of children, even though those benefits are the consequence of circumstances beyond the control of the parents.

In sum, even assuming neutrahty as to parental interests, consideration of gender in custody disputes is not per se unconstitutional and, contrary to the holdimg in Watts, it is permissible for a court to rely on gender as the determinative factor where such reliance produces the most child-protective result. The fact is, however, that the instances in which an interspousal custodial award would turn on gender or on biological motherhood alone are unlikely to arise with any frequency, because in most cases one parent lias been the primary caregiving parent. A custodial award to a primary caregiving mother is not based solely on gender, and the mother's gender/motherhood is probably not sufficient to justify maternal custody where the father has clearly performed the mothering function. Most cases will turn on who the primary caregiver is-a fact that does not necessarily turn on gender and that can be determined apart from gender. Thus the broader question is whether a gender-specific tender years presumption in favor of inaternal custody based on mothering, not gender, violates the father's rights to equal protection under the fourteenth amendment.

\section{B. The Constitutionality of the Gender-Specific Rebuttable Tender Years Presumption}

The objective of the tender years presumption is the principled and child-protective resolution of interspousal custody disputes. The policy of the presumption is to serve the broad objective by favoring the custodial alternative that leaves the child in the care of the parent who, before the separation, had the primary responsibility for the child's day-to-day care. The policy is based on the assumption that the primary caregivimg parent is likely to be better able to provide the care and attention that the child needs and that this choice will maximize continuity and minimize the disruptive effects of the divorce. To the 
extent that the burden falls on a father to prove that a custodial award to a mother who has been the primary caregiving parent is not in the child's best interests, the burden is not gender-based. Rather, it is based on the fact that he is not the primary caregiving parent.

The statistical congruence between being the female parent and being the primary caregiver is, of course, very high-certainly over ninety percent and probably close to complete. ${ }^{133}$ Consequently, even a gender-neutral preference for the primary caregiving parent might be attacked as having a disparate impact on male and feinale parents. At this point, however, the very real conflict between the interests of the children and the promotion of equal parental interests, as distinguished from the promotion of gender-neutrahty, emerges clearly. To abandon the tender years presumption im order to achieve equal distribution of custody awards to fathers and mothers would be to sacrifice the interests of children to the protection of fathers' rights in children, thereby inarking a retreat to common law priorities rejected more than a century ago. It cannot be seriously argued that the fourteenth amendment requires so absurd a result. ${ }^{134}$

133. Census Bureau figures indicate that of all married women living with their husbands, fewer than one-third work full-time. Of those with children under 6 , only $25 \%$ work full-time. Hacker, E.R.A.-R.I.P., Sept. 1980, at 10, 11, 14. Moreover, even where both parents are working full-time, the mother typically has the primary responsibility for running the household and car* ing for the children, even in very "liberated" households. See, e.g., Miller, The Making of a Confused Middle-Class Husband, 2 Soc. PoL'y 33 (1971), excerpted in J. AREEN, FAMILY LAW 145 (1978):

True, my wife has always worked at her profession (she is a physician), even when our sons were only some weeks old. True, I help im many ways and feel responsible for her having time to work at her professional interests. But I do partial, limited things to frce her to do her work. I don't do the basic thinking about the planning of meals and housekceping, or the situation of the children. Sure, I will wash dishes and "spend time" with the children; I will often do the shopping, cook, make beds, "share" the burden of most household tasks; but that is not the same thing as direct and primary responsibility for planning and managing a household and meeting the day-to-day nceds of children.

Id. at $146-47$.

Following Personnel Adm'r v. Feeney, 442 U.S. 256 (I979), such a disparate impact is not fatal, given a permissible statutory intent. Here the intent is to favor the custodial alternative that leaves the child in the care of the parent who before the separation had the primary responsibility for the child's day-to-day care. The underlying assumption is that this parent is likely to be better able to provide the care and attention that the child needs and that this choice will maximize continuity of care and ininimize the disruptive effects of the divorce. Thus, the presumption is constitutional despite its discriminatory impact.

134. In addition, it cannot be ignored that performance of the "inothering function" has significant consequences for the primary caregiving parent as well as the child, not the least of which is that the parent has a considerable investunent of emotion and time in caregiving and a concomitant withdrawal from other social functions. While both parents have a protectible interest in continued companionship of, and supervision over, the child, recognition of the primary caregiving parent's interest in continuing as primary caregiver as paramount to the nonprimary caregivimg parent's interest in becoming the primary caregiver seems entirely reasonable and fair. Thus, a pohicy of granting custody to the primary caregiving parent unless the child's interests require an alternative disposition is probably independently justifiable with respect to parental interests. 
In any event, a gender-neutral preference for the primary caregiving parent plainly does not violate the fourteenth amendment. Is then a functionally equivalent presumption in favor of inaternal custody unconstitutional because it is expressed as a gender-specific presumption? The answer is probably no.

First, as already noted, "mother" (i.e. gender) is an extremely accurate proxy for "primary caregiving parent."135 In addition, there is a significant biological connection between gender and the capacity and willingness to perform the mothering function. ${ }^{136}$ This is, therefore, not only, as the Oklahoma Supreme Court held, one of "those instances where the sex-centered generalization actually [comports] to fact,"137 but also an instance in which the presumably sex-related behavior is in fact based in part on biological sex differences. Finally, the assumption that the female parent is the primary caregiving parent is rebuttable: no father is deprived of an individualized hearing, where he can attempt to show that paternal custody will better ineet a child's immediate developmental needs; and no primary caregiving father is denied custody solely because of his gender.

The gender-specific presumption has the potential for discriminating substantively in favor of mothers on the basis of gender only if it is used as a tie breaker. Where both parents offer acceptable custodial alternatives and, since the child's birth, have shared so equally in its day-to-day care that neither can be identified as the primary caregiving parent, a maternal preference presumption tips the balance in favor of the mother. In cases involving pre-school age children, preference for the mother based on the biological mother-child relationship is a defensible and permissible policy choice. For children over five or six, however, the weight accorded the biological mother-child relationship generally should be lessened since it is probably too remote to justify a gender-based maternal preference. ${ }^{138}$ However, any potential constitutional infirmity could be avoided simply by not using the presuinptive rule as a tie breaker between equal caregiving parents of school age children.

Apart from its tie-breaking potential, the gender-specific presumption affects similarly situated fathers and inothers differently only in

135. See supra text accompanying note 104 .

136. See supra notes 119-23.

137. Gordon v. Gordon, 577 P.2d 1271 (Okla.), cert. denied, 439 U.S. 836 (1978).

138. However, one possible justification for a maternal preference tie breaker for older as well as younger children is that an alternative tie breaker, given the high rate of divorce, might encourage competition between parents during marriage and lead mothers to guard their primacy by preventing what they perceive to be too much father involvement in child care. This competition obviously would be detrimental to the children and to the marriage without increasing the likelihood of paternal custody after divorce. 
that a primary caregiving father, but not a primary caregiving mother, has a threshold burden of producing credible evidence that he is in fact the primary caregiving parent. If a father does not produce such evidence, the mother and the court may rely on the presumption that the mother is the primary caregiving parent, and thereby avoid a pointless evidentiary presentation by the inother. Once the father does make a threshold showing that he is the primary caregiving parent, and thus that paternal custody would better serve the child's immediate developmental needs, the mother must necessarily produce contrary evidence in order to prevail. At this point, the proceedings are no different than they would be under a gender-neutral rule.

In short, what we are talking about at this point is in practical effect a procedural device that requires a very small percentage of primary caregiving fathers to do precisely what they would have to do under a gender-neutral primary caregiver presumption. The overwhelming advantage of the maternal preference rule is avoidance of a full-scale evidentiary inquiry into the threshold issue of which parent is the primary caregiving parent in the vast najority of cases where the mother is in fact the primary caregiving parent. Assuming that the "burden" thereby placed on the primary caregiving father is even constitutionally significant, it can readily be justified by a state interest in facilitating the speedy, ordered, and minimally burdensome resolution of custody disputes. If not for the sake of judicial economy or to protect the great majority of primary caregivers, ${ }^{139}$ the burden certainly can be justified on behalf of the children of divorce for whom delay, unnecessary litigation, and unnecessarily bitter litigation is plamly detrimental.

The question then is whether the mere availability of a functionally equivalent gender-neutral classification renders unconstitutional a rebuttable gender-specific classification where the congruence between gender and the characteristic it purports to represent is virtually complete. The Supreme Court is not likely to answer this question affirmatively, because such a result would make the intermediate level of scrutiny described in Craig v. Boren, ${ }^{140}$ indistinguishable from "strict" scrutiny, a standard the Court has declined to employ in reviewing gender-centered classifications. Moreover, insistence on gender neutrality

139. Fathers who do not really want the responsibilities of daily child care sometimes use custody as a means of extortion. As one commentator has pointed out, the less secure a mother's custodial advantages, the more likely she is to accede to unfavorable settlements that leave her and the children at the brink of poverty rather than to risk losing the children. Uriller, Fathers' Rights and Feminism: The Maternal Presumption Revisited, 1 HARv. WOMEN's L.J. 107, 127 (1978) (endorsing the tender years doctrine on feminist grounds). A state surely has a legitimate intercst in minimizing this abuse sufficient to justify procedural safeguards.

140. 429 U.S. 190, 210 (1976) (Powell, J., concurring). 
in the face of gender-specific realities distorts the purpose of the fourteenth amendment, which is to protect against arbitrary discrimmation. Indeed, this very distinction between prohibiting arbitrary discrimination and requiring gender-blindness lies at the heart of the controversy over the Equal Rights Amendment (ERA). Whetler the ERA, if ratified, should or would be construed as requiring absolute gender-neutrality in all circumstances, is a question beyond the scope of the Article. ${ }^{141}$ What is clear is that absent passage of the ERA or the Supreme Court's reading a broad requirennent of gender neutrality into the fourteenth amendinent, a rebuttable gender-specific tender years presumption probably would be uplield agaimst a fourteenth amendment attack.

Most importantly, lowever, even if the gender-specific presumption were found unconstitutional -or if a state were to decide as a unatter of policy that gender specificity was undesirable-the reinedy would not be to reject the presumption as the Watts decision did, but to "neutralize" it by substituting a gender-neutral presuinption in favor of the primary caregiving parent. Only in this way can the interests of children remain distinct froin and paranount to the conflict between parental interests in children.

\section{CONCLUSION}

Criticism of the tender years doctrine as inconsistent with the "best interests of the child" principle is largely without merit. Historically, the doctrine has presented some problems because of its largely outdated "unfitness" standard of rebuttal, which incorrectly focused on the social conduct of the parents rather than on the developinental needs of children. This problein can be-and in many jurisdictions lias beenremedied by adoption of a rebuttable standard that instead focuses on the best interests of the child. The underlying policy is to place a child in the physical custody of the parent who liad primary responsibility for the child's day-to-day care during the marriage, absent a positive showing that an alternative placennent will better serve the child's needs.

Tlius refined, the tender years doctrine-expressed as a preference either for nothers or for primary caregiving parents-is inore child protective than the ad hoc approacl advocated by critics of the doctrine. In addition, the doctrine deals equitably with the conflict between parental interests by preserving the role choices inade by the parents during their inarriage.

141. For a relevant discussion of the constitutional scrutiny of gender-based classifications, see F. Zimring, The Changing Legal World of Adolescence 26-28, 86-87 (1982). 
Criticism of the tender years doctrine as impermissible sex discrimination is also largely without inerit. Whether the doctrine is expressed as a gender-neutral presumption in favor of the primary caregiving parent or a gender-specific presumption in favor of maternal custody is probably of no constitutional significance and certainly of no practical consequence since either will result overwhelmingly in inaternal custody. Moreover, a gender-based preference for the mother is itself sound as a tie breaker between equally caregiving parents of the young children.

The inore profound issues touched on in this Article-the extent to which men can, will, or should be socialized to be primary (or even equal) caregivers-are highly controversial. With respect to these questions, it is important that the rhetoric of sexual politics is not substituted for evidence. Whatever gender-based differences do exist between men and women are plainly irrelevant to, and provide no justification for, sex discrimination in the vast majority of social functions. It is therefore not necessary to pretend complete fungibility between the sexes in order to achieve equal opportunity and equal treatment in employinent and education or to protect the role choices of men and woinen. Where, however, social functions may be tied intimately to male and fernale sexuality, ideological insistence on sameness-or differences-serves only to obscure the potential consequences of individual and societal choices. 